\title{
Phytochemical studies on traditional herbal medicines based on the ethnopharmacological information obtained by field studies
}

\author{
Naonobu Tanaka ${ }^{1}$ (D) $\cdot$ Yoshiki Kashiwada $^{1}$ (D)
}

Received: 28 May 2021 / Accepted: 26 June 2021 / Published online: 13 July 2021

(c) The Author(s) 2021

\begin{abstract}
Traditional herbal medicines, which have been used in the matured traditional medical systems as well as those have been used in ethnic medical systems, are invaluable resources of drug seeds. Ethnobotanical and ethnopharmacological survey may provide useful information of these herbal medicines, which are valuable for searching new bioactive molecules. From this viewpoint, we have been performing the ethnobotanical and ethnopharmacological field studies in Yunnan Province and Guangxi Zhuang Autonomous Region, China, and Mongolia. Phytochemical studies on traditional herbal medicines were performed based on the information obtained by our ethnobotanical survey. Herbal medicines used in Uzbekistan and Bangladesh were also investigated on the basis of the ethnopharmacological information obtained from collaborative researchers in the respective regions. Some studies were carried out for searching active substance(s) based on bioassay-guided fractionation and isolation. Over 150 new molecules were isolated in these studies, and their various biological activities were also demonstrated. This review summarizes the results of phytochemical studies of those traditional herbal medicines as well as biological activities of the isolated molecules.
\end{abstract}

\section{Graphic abstract}

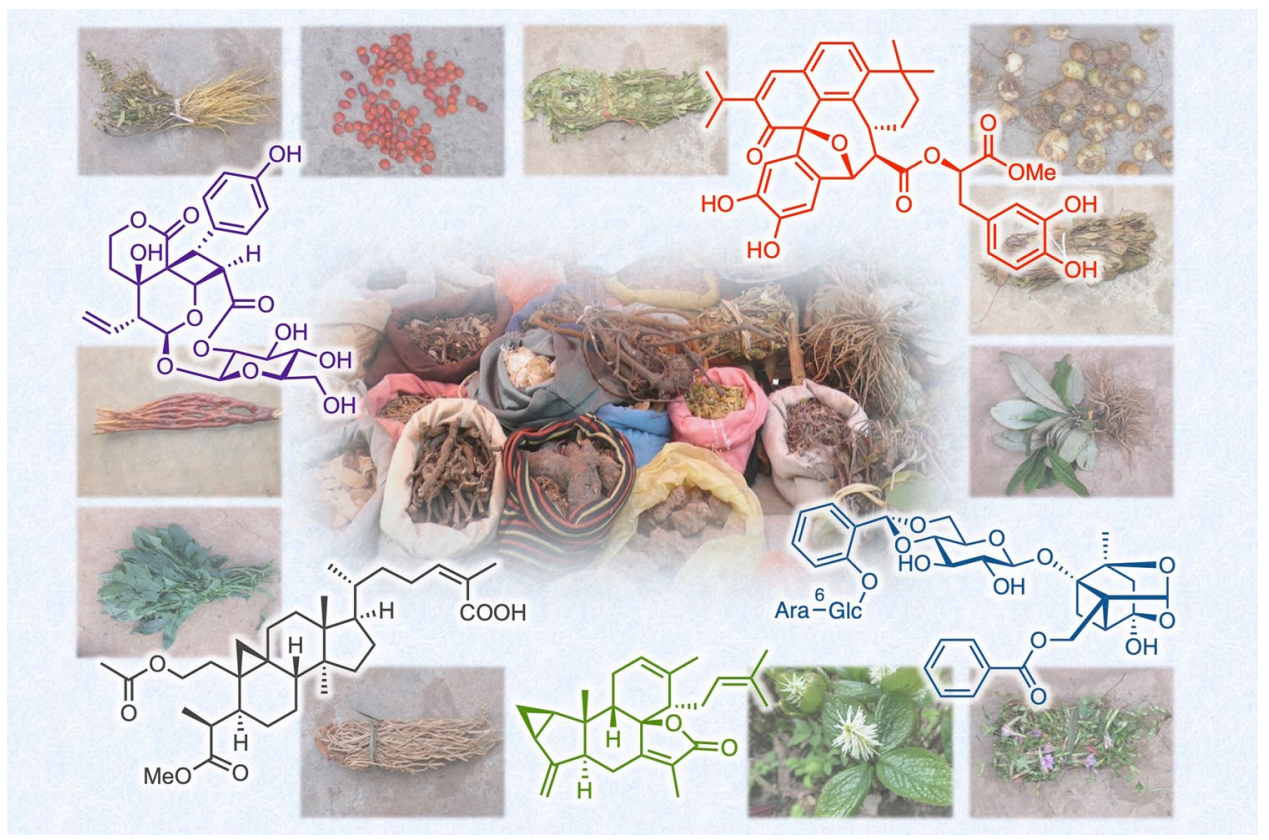

Keywords Phytochemical study $\cdot$ Field study $\cdot$ Traditional herbal medicine $\cdot$ Ethnopharmacological information

Extended author information available on the last page of the article 


\section{Introduction}

A variety of herbal medicines have been utilized in traditional medical systems as well as ethnic populations in various areas of the world. Natural products, particularly unique secondary metabolites found from those herbal medicines, including those have been used in not only traditional medical systems but also ethnic medical systems, provide potential molecules to develop new drug candidates. Therefore, these herbal medicines are considered to be invaluable resources of drug seeds molecules on which new therapeutic agents can be based. Chinese, Ayurvedic, and Unani are matured traditional medical systems, where several knowledges of herbal medicines have been documented. In contrast, some ethnic medical systems employ unique uses of herbal medicines or those prepared from endemic resources in respective regions. In addition, some of those knowledges have been preserved through the ages, in some case, simply in orally, and those remained only in isolated ethnic groups [1]. Ethnobotany and ethnopharmacology, a kind of scientific field study for interrelations between ethnic people and herbal medicines, may provide undocumented unique information of herbal medicines leading ideas of research to find sources of new molecules [2]. From this viewpoint, we have been collaborating with researchers in several countries, of which some have been performing ethnobotanical and ethnopharmacological surveys with the researchers based on the academic agreements between universities, while the others are collaborative studies with the researchers based on the exchange of ethnopharmacological information. In this review, research progress of our phytochemical studies on traditional herbal medicines used in China, Mongolia, Uzbekistan, and Bangladesh will be described.

\section{Geographical and ethnobotanical features of Yunnan Province and Guangxi Zhuang Autonomous Region, China}

China has 55 minority groups, recognized officially by the government, that settled in particular areas and have been using a variety of ethnic herbal medicines as their own remedies different from the matured Chinese traditional medical system. Yunnan Province and Guangxi Zhuang Autonomous Region are the areas, where many ethnic minority groups are living. Yunnan, an inland province at a low latitude in southwestern China, has a characteristic geographical feature with the large height difference; the lowest point of $76.4 \mathrm{~m}$ above sea level at the Red River at the southeast edge, and the highest point of $6740 \mathrm{~m}$ at the summit of Kagebo peak. The climate of Yunnan Province is also affected by geographic location neighboring tropical and subtropical regions. For this reason, Yunnan has a vast diversified and unique natural resources, where more than 18,000 higher plant species are distributed [3]. In contrast, limestone areas of Guangxi Zhang Autonomous Region cover up to $40 \%$ areas of this province, which comprises one of the largest limestone areas of the world if considering to combine with limestone areas of neighboring Guizhou and Yunnan provinces, and North Vietnam. A diverse flora of over 8000 vascular plants and very high levels of endemism, in which 10 genera and 744 species, are endemic to this area [4].

\section{Phytochemical studies on traditional herbal medicines used in Yunnan Province}

Twenty-five ethnic minority groups, out of 55 recognized officially by the Chinese government, live in their own autonomous areas in Yunnan Province, and those minority groups have long used many of diverse plants grown in Yunnan as their own unique herbal medicines. Our group performed an ethnopharmacological survey collaborated with researchers of the Kunming Institute of Botany, Chinese of Academy of Sciences, and some phytochemical studies based on the information obtained in the ethnopharmacological survey.

The genus Gentiana, the largest member of Gentianaceae, consists of about 400 species. Various Gentiana plants have been included in herbal remedies for poor appetite and digestive problems worldwide [5]. G. rigescens Franch. ex Hemsl. grows in southwestern part of China, especially in the mountain areas of Yunnan Province. The roots of G. rigescens, one of the varieties of Gentianae Radix (Long-Dan) in Chinese Pharmacopeia, have been commonly used as a traditional Chinese medicine, for the treatment of inflammation, and for hepatitis, rheumatism, and cholecystitis [6]. It also has been used for the treatment of hepatitis and cholecystitis by the Yi ethnic minority group living in Yunnan Province.

We conducted the phytochemical investigation on the aerial parts of $G$. rigescens. Thus, the $\mathrm{MeOH}$ extract of this plant material was partitioned between EtOAc and $\mathrm{H}_{2} \mathrm{O}$, and the EtOAc-soluble fraction was further partitioned between $n$-hexane and $90 \% \mathrm{MeOH}$ aq. The $50 \% \mathrm{MeOH}$ aq.-soluble materials, obtained by subsequent partition of the $90 \% \mathrm{MeOH}$ aq.-soluble materials with $\mathrm{CHCl}_{3}$ and $50 \%$ $\mathrm{MeOH}$ aq., were separated by chromatographies repeatedly to isolate seven new acylated secoiridoid glucosides, a new secoiridoid, and three new noriridoids as well as seven related known compounds including macrophylloside A. Their structures were assigned by detailed spectroscopic analyses and chemical evidence [7,8]. 
Among new acylated secoiridoid glucosides, rigenolide A (1) had a unique structure with a cyclobutane ring, being formed by intramolecular [2+2] cycloaddition between swertiamarine moiety and $p$-coumaroyl group bound to $\mathrm{C}-2^{\prime}$ of swertiamarine. This was the first example of a secoiridoid glucoside having a cyclobutane ring. Compound $\mathbf{6}$ was isolated as a partially racemic mixture. In contrast, repeated chromatographic separations of the $\mathrm{H}_{2} \mathrm{O}$-soluble materials gave two new conjugates of norsecoiridoid and secoiridoid glucoside, rigenolides B (7) and C (8) [9]. The structures of $\mathbf{7}$ and $\mathbf{8}$ were elucidated on the basis spectroscopic analysis, chemical conversion, and TDDFT ECD calculation. Compound $\mathbf{6}$, corresponding to the noriridoid moiety of $\mathbf{7}$ and $\mathbf{8}$, might yield a pair of diastereomers corresponded to $\mathbf{7}$ and $\mathbf{8}$ by condensation with gentiopicroside. Macrophylloside A showed potent DPPH free-radical scavenging activity with an $\mathrm{IC}_{50}$ value of $16.2 \mu \mathrm{M}$, which was more potent than that of L-ascorbic acid used as a positive control. In contrast, $\mathbf{2 - 5}$, possessing a 2,3-dihydroxybenzoyl moiety, showed moderate radical scavenging activities with $\mathrm{IC}_{50}$ values ranging from 36.4 to $48.2 \mu \mathrm{M}$, while $\mathbf{1}$ did not show a radical scavenging activity (Fig. 1).

Plants belonging to the genus Chloranthus (Chloranthaceae) are recognized as a rich source of sesquiterpenes, especially lindenane sesquiterpenes represent taxonomically characteristic secondary metabolites of the Chloranthus plants [10]. C. spicatus (Thunb.) Makino is an evergreen shrub native to southern China, and is also a horticultural plant widely cultivated in eastern Asia. We came to know in our ethnopharmacological study that the roots of $C$. spicatus have been used to treat bone fractures by the Va ethnic group, while the Dai ethnic group has been using this plant to treat high blood pressure. Chemical study on the roots of $C$. spicatus lead to the isolation of two new lindenane sesquiterpene dimers with an 18-membered macrocyclic ring, spicachlorantins A (9) and B (10), along with a known related compound, chloramultilide A (Fig. 2) [11]. The absolute configurations of $\mathbf{9}$ and $\mathbf{1 0}$ were elucidated by ECD spectroscopic analysis. Shizukaol B, a dimeric lindenane sesquiterpene possessing a macrocyclic ring, from C. japonicus was reported first in 1992 [12]. The related dimeric lindenane sesquiterpenes, shizukaols F, G, and $\mathrm{H}$, from the same plant material were subsequently reported in 1995 [13]. Later on, further seven related dimeric lindenane sesquiterpenes from $C$. multistachys, $C$. holostegius, $C$. henryi, $C$. tianmushanensis, and $C$. fortunei were reported between 2006 and 2009 [14], and our report of the isolation of $\mathbf{9}$ and $\mathbf{1 0}$ from C. spicatus in 2009 followed those ones. Since the plant materials, $C$. spicatus, obtained in our survey in Yunnan were small, further investigation was carried out with cultivated plant materials, which resulted in the isolation of eight new lindenane sesquiterpene dimers, spicachlorantins $\mathrm{C}-\mathrm{J}$, along with seven known related sesquiterpene dimers. Spicachlorantins C-F (11-14) were the first examples of lindenane sesquiterpene dimers with a hydroperoxy group at C-4, and were considered to be biogenetic precursors for the corresponding hydroxy derivatives of dimeric lindenane sesquiterpenes distributed in Chloranthus plants. Spicachlorantin A (9) was also isolated from C. angustifolius by Yang et al., and its antifungal activity against Candida
Fig. 1 The structures of rigenolides A (1), B (7), C (8), F (3), $\mathrm{G}(\mathbf{4})$, and $\mathrm{H}(\mathbf{5})$, noriridoid (6), and macrophylloside A isolated from Gentiana rigescens

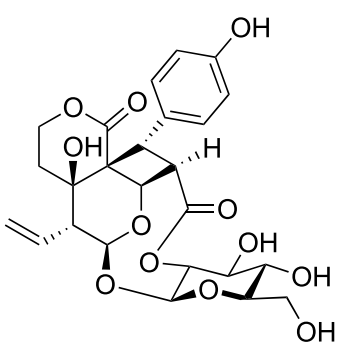

1

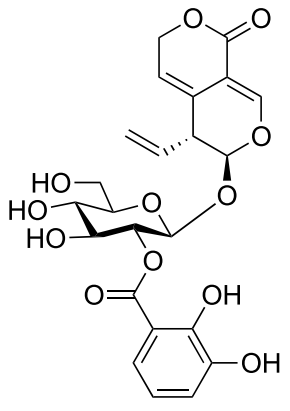

2

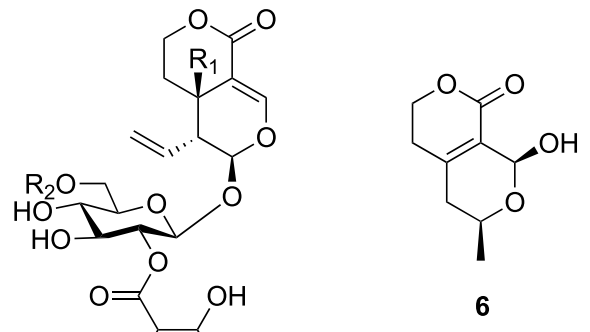<smiles>Oc1ccccc1</smiles>

$\begin{array}{ccc} & \mathrm{R}_{1} & \mathrm{R}_{2} \\ \mathbf{3} & \mathrm{H} & \mathrm{H} \\ \mathbf{5} & \mathrm{H} & \mathrm{Ac} \\ \mathbf{5} & \mathrm{OH} & \mathrm{H}\end{array}$

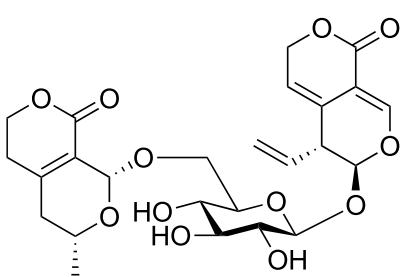

7

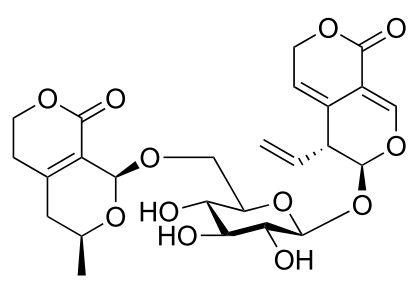

8

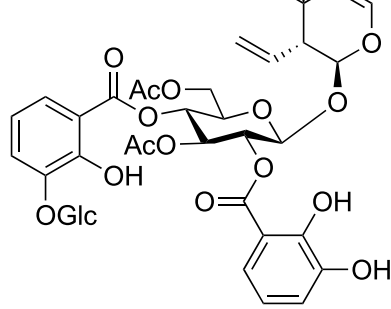

macrophylloside A 


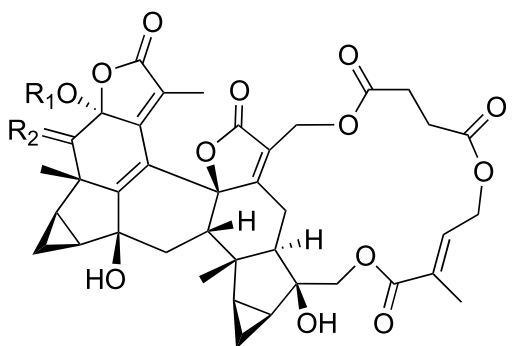

$\begin{array}{ccc} & \mathrm{R}_{1} & \mathrm{R}_{2} \\ \mathbf{9} & \mathrm{H} & \mathrm{O} \\ 10 & \mathrm{Me} & -\mathrm{OH}, \mathrm{H}\end{array}$

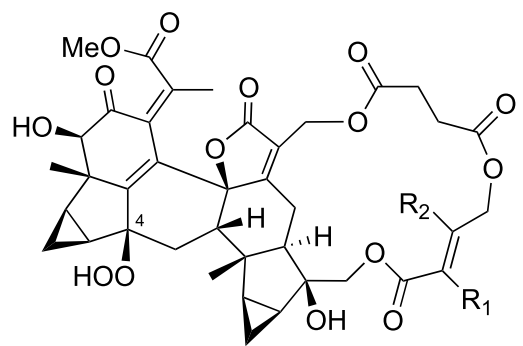

\section{$\begin{array}{lll}\mathrm{R}_{1} & \mathrm{R}_{2}\end{array}$}

$11 \mathrm{Me} \mathrm{H}$

$12 \mathrm{H}$ Me

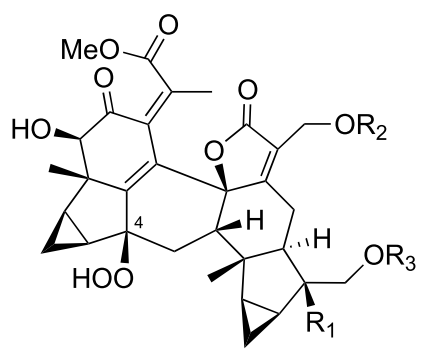

$\begin{array}{ccccc}\mathrm{R}_{1} & \mathrm{R}_{2} & \mathrm{R}_{3} \\ 13 & \mathrm{OH} & \mathrm{Ac} & \mathrm{Tig} \\ 14 & \mathrm{H} & \mathrm{H} & \mathrm{Ac}\end{array} \quad \mathrm{Tig}=2_{2}$

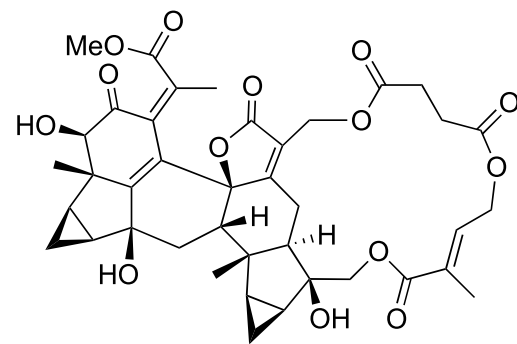

chloramultilide A

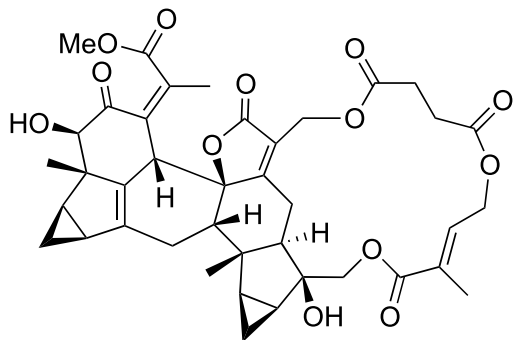

shizukaol B

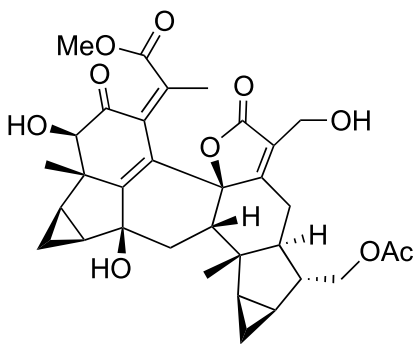

15

Fig. 2 The structures of spicachlorantins A-G (9-15), chloramultilide A, and shizukaol B isolated from Chloranthus spicatus

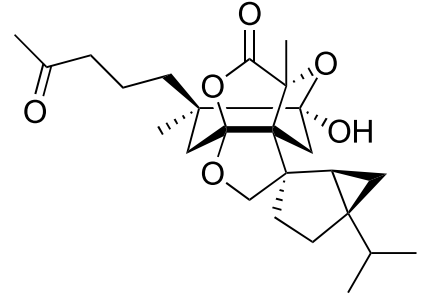

16

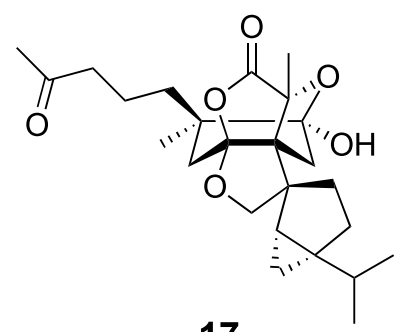

17
Fig. 3 The structures of hitorins A (16) and B (17) isolated from Chloranthus japonicus

albicans (MIC $8 \mu \mathrm{g} / \mathrm{mL}$ ) was reported [15]. In contrast, Wang et al. reported the isolation of spicachlorantins B (10) and $\mathrm{G}(\mathbf{1 5})$ from $C$. henryi, and demonstrated their antineuroinflammatory effect $\left(\mathrm{IC}_{50}\right.$ values of 79.4 and $70.4 \mu \mathrm{M}$, respectively) by inhibiting nitric-oxide (NO) production in lipopolysaccharide (LPS)-stimulated murine BV-2 microglial cells with relatively low cytotoxicity [16].

The findings of structurally unique secondary metabolites from C. spicatus prompted us to study on the constituents of C. japonicus as an extensive study of this research project. C. japonicus (hitorishizuka in Japanese) has been used as a herbal medicine by the Ainu people, an ethnic minority group living in Hokkaido, Japan, for the treatment of gastrointestinal disorders. This study resulted in the isolation of two novel $\mathrm{C}_{25}$ terpenoids with a 6/5/5/5/5/3 hexacyclic skeleton, hitorins A (16) and B (17) (Fig. 3) [17]. Hitorins A (16) and B (17) were considered to be biogenetically derived from eudesmane sesquiterpene and thujane monoterpene. Biomimetic synthesis of $\mathbf{1 6}$ and $\mathbf{1 7}$ has been reported by $\mathrm{Li}$ et al. as a preprinted manuscript in the ChemRxiv [18]. Evaluation of biological activities of $\mathbf{1 6}$ and $\mathbf{1 7}$ as well as further explorative study of the related terpenoids are underway.

Rubia yunnanensis (Rubiaceae) is a perennial climbing herb distributed in mainland China. The roots of $R$. yunnanensis have been used as a herbal medicine to treat cancer, vertigo, insomnia, rheumatism, tuberculosis, menstrual disorders, and contusions [19]. Three new naphthoquinones, rubiaquinones $\mathrm{A}-\mathrm{C}(\mathbf{1 8}-\mathbf{2 0})$, were isolated from the 70\% acetone aq. extract of the $R$. yunnanensis roots. Rubiaquinone A (18) was a racemic naphthoquinone dimer, while rubiaquinones $B(\mathbf{1 9})$ and $C(\mathbf{2 0})$ were structurally unique trimeric naphthoquinones with a racemic nature possessing one chiral axis and one chiral carbon in common (Fig. 4) [20]. The absolute configurations of (+)-18 and (-)-18, obtained by optical resolutions using chiral HPLC, were elucidated by interpretation of the ECD spectra with the aid of TDDFT ECD calculation. By contrast, the absolute configurations of optically active stereoisomers obtained from ( \pm -19 and ( \pm )-20 were successfully assigned by analyses of the composite ECD spectra generated by summing ECD spectra of appropriate enantiomers. Racemic rubiaquinone A (18) exhibited antimicrobial activity against Bacillus subtilis (MIC $4 \mu \mathrm{g} / \mathrm{mL}$ ). 
Fig. 4 The structures of rubiaquinones A-C (18-20) isolated from Rubia yunnanensis

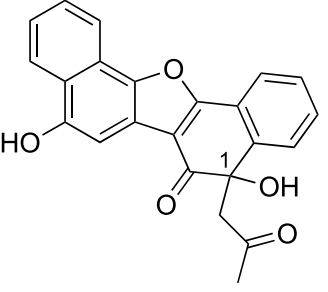

$(+)-18: 1 R$

$(-)-18: 1 S$
Scutellaria plants, belonging to the Lamiaceae family, include about 350 species, and are widely distributed in temperate zone and tropical zone of Europe, North America, and East Asia. Many of them have been used as herbal medicines in various countries [21]. For example, the roots of $S$. baicalensis have been used as a pharmacopoeial medicine for removing fever and inflammation in Japan and China [22, 23], while the aerial parts of $S$. galericulata have been used as a sedative and an antispasmodic in United States [24]. Flavonoids, flavonoid glycosides and neo-clerodane type diterpenes were shown to be major constituents of the Scutellaria plants by previous studies. Biological activities including anticancer, antiinflammatory and antifeedant activity of the isolated compounds were also reported [25]. We had an opportunity to learn that $S$. coleifolia is distributed in high altitude regions of Yunnan and Sichuan Provinces. The scientific studies of this plant have not been previously performed, although many biologically active compounds have been isolated from Scutellaria plants. Since finding new drug seeds from unexplored plant resources was also of our interest, we investigated the constituents of the aerial parts of $S$. coleifolia, which resulted in the isolation of two new sesterterpenes, coleifolides A (21) and B (22), and twentynine new diterpenes, together with six known compounds (Fig. 5). Coleifolides A (21) and B (22) were rare sesterterpenes from terrestrial plant [26], structurally similar to a marine sesterterpene, manoalides [27]. They were shown to be partial racemates, and the absolute configurations of their major isomers were assigned by analysis of the ECD spectra as well as NMR data for $(R)$ - and $(S)$ methoxyphenylacetic ester derivatives. In contrast, twentynine new diterpenes include two acylated neo-clerodanes with a 19,18- $\gamma$-lactone, scutefolides A1 (23) and A2 (24) $[28,29]$. Coleifolides A (21) and B (22) showed moderate cytotoxicity against four cancer cell lines, KB (epidermoid carcinoma), A549 (lung carcinoma), HeLa (uterine carcinoma), and MCF7 (breast carcinoma) cell lines, with $\mathrm{IC}_{50}$ value ranging from 13.6 to $37.6 \mu \mathrm{g} / \mathrm{mL}$. In contrast, diterpenes exhibited weak or no cytotoxicity.
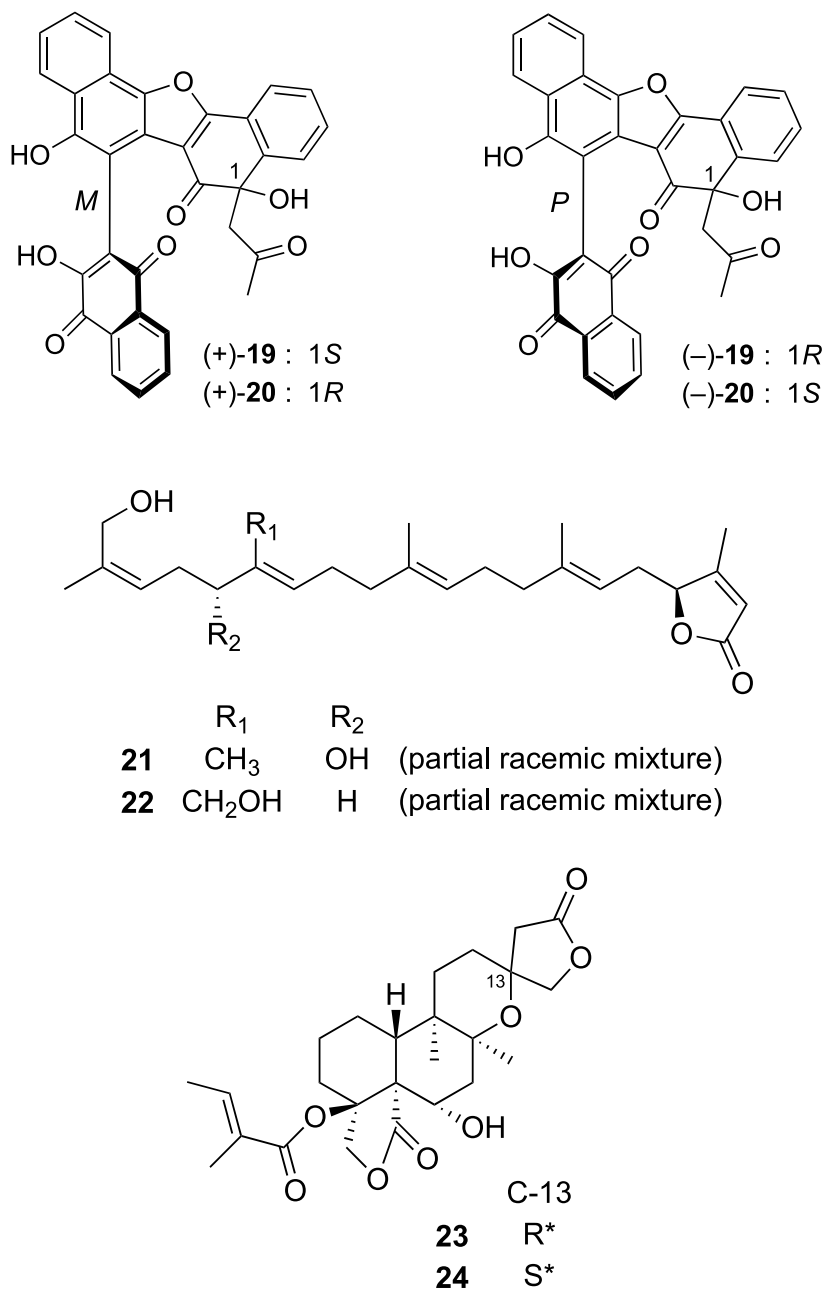

Fig. 5 The structures of coleifolides A (21) and B (22) and scutefolides A1 (23) and A2 (24) isolated from Scutellaria coleifolia

\section{Phytochemical studies on traditional herbal medicines used in Guangxi Zhuang Autonomous Region}

Zhuang and Yao are two major minority groups in Guangxi Zhuang Autonomous Region, whose traditional medicines, Zhuang and Yao medicines, respectively, possessing over thousand years' history, have been mainly used for the treatments of rheumatism, snakebite, malaria, cold, cancers, and skin problems. Approximately 4,000 medicinal plant species are seen in Guangxi, accounting for more than one-third of Chinese medicinal plant resources. Moreover, around 500 medicinal plants have been used as remedial agents in Zhuang medicine, while over 400 ones have been used in Yao medicine. These medicinal plants were selected mainly based on local flora, most of which were collected from the wild ecosystems [30]. We have been interested in these attractive traditional herbal 
medicines, and carried out phytochemical studies of them based on our collaborated ethnopharmacological study with researchers of the Guangxi Institute of Botany, Chinese of Academy of Sciences.

Plants belonging to the genus Munronia (Meliaceae) are perennial herbs widely distributed in China, Sri Lanka, India, Indonesia, and the Philippines [31]. Among others, M. pinnata (Wall.) W. Theob. (synonyms: M. henryi Harms, M. pumila Wight, and M. sinica Diels) is a traditional herbal medicine used in China for the treatments of tuberculosis, cough, stomachache, and sores. Phytochemical investigation on the aerial parts of Munronia pinnata obtained at Jingxi, Guangxi gave six new limonoids including munropins A (25), B (26), and F (27) (Fig. 6) [32]. Munropins A (25) and B (26) possessed a prieurianin skeleton with $\alpha, \beta$ unsaturated $\gamma$-lactam moieties at $\mathrm{C}$-17. In contrast, munropin $\mathrm{F}(\mathbf{2 7})$ was assigned to have a nimbolinin type skeleton with a $\gamma$-hydroxy- $\alpha, \beta$-unsaturated $\gamma$-lactone moiety. Their structures were assigned by detailed spectroscopic analyses.

A Chloranthaceous plant, Sarcandra glabra (Thunb.) Nakai [synonym: Chloranthus glaber (Thunb.) Makino], is a perennial herb distributed in Japan, southern parts of mainland China, and southeastern Asia. The whole plants of S. glabra have been used as a traditional herbal medicine for the treatments of infectious disease and cancer in China [33]. The aerial parts of S. glabra collected Gongcheng, Guangxi were investigated to give new structurally interesting terpenoids, sarcaglabrins A-C (28-30) (Fig. 7) [34], together with 22 known related compounds including shizukaols $\mathrm{C}$ and $\mathrm{D}$, chlorahololide $\mathrm{D}$, and sarcandrolide $\mathrm{E}$.
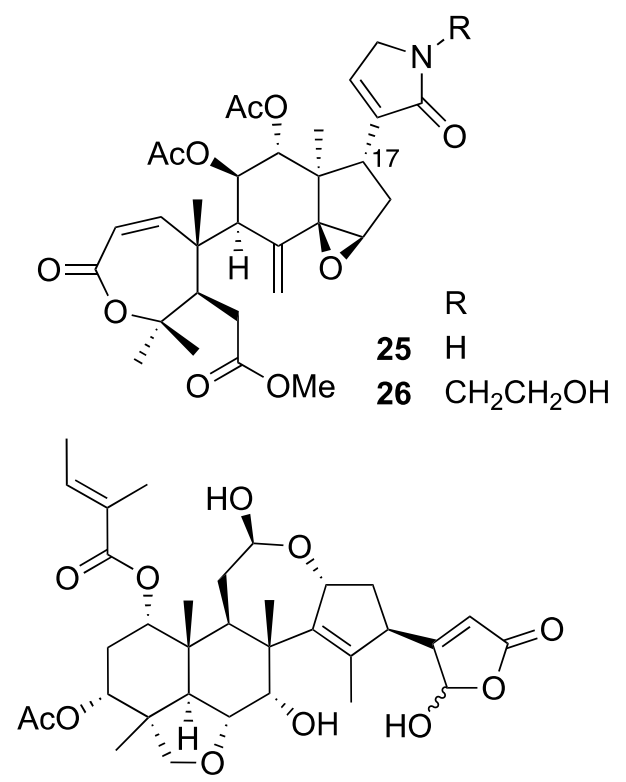

27

Fig. 6 The structures of munropins A (25), B (26), and F (27) isolated from Munronia pinnata

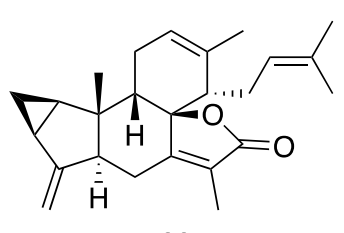

28

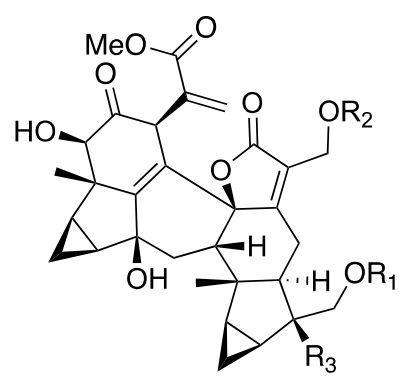

$\begin{array}{lll}\mathrm{R}_{1} & \mathrm{R}_{2} & \mathrm{R}_{3}\end{array}$

29 Tig $\mathrm{Ac} O \mathrm{OH}$

shizukaol $\mathrm{C}$ Tig $\mathrm{H} \mathrm{OH}$ shizukaol D Ac $\mathrm{H} \quad \mathrm{H}$ chlorahololide D Tig Ac OH

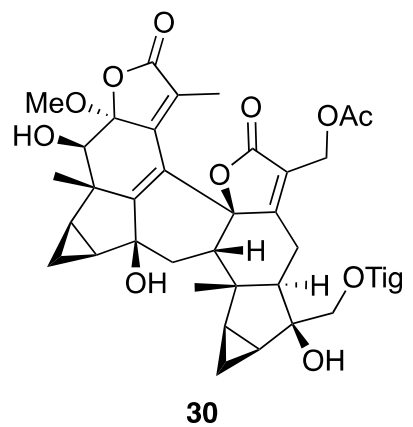

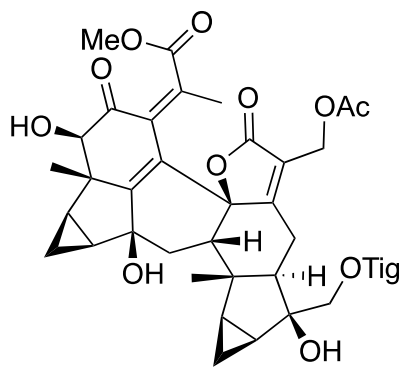

sarcandrolide $E$
Fig. 7 The structures of sarcaglabrins A-C (28-30), shizukaols $\mathrm{C}$ and $\mathrm{D}$, chlorahololide D, and sarcandrolide E isolated from Sarcandra glabra

Sarcaglabrin A (28) was assigned as a conjugate of lindenane type sesquiterpene and ocimene type monoterpene, while sarcaglabrins B (29) and C (30) were elucidated to be lindenane sesquiterpene dimers. In an evaluation of the antiproliferative activity against three human cancer cell lines, HeLa, MCF7, and A549, for the isolated compounds, shizukaols $\mathrm{C}$ and $\mathrm{D}$, chlorahololide $\mathrm{D}$, and sarcandrolide $\mathrm{E}$ were shown to exhibit weak cytotoxicities against Hela cells with $\mathrm{IC}_{50}$ values of $44.3,43.0,32.2$, and $37.9 \mu \mathrm{M}$, respectively, while sarcandrolide $\mathrm{E}$ was also found to show a weak activity against MCF7 cells with an $\mathrm{IC}_{50}$ value of $46.5 \mu \mathrm{M}$. However, sarcaglabrins A-C (28-30) did not show cytotoxicity $\left(\mathrm{IC}_{50}>50 \mu \mathrm{M}\right)$.

\section{Phytochemical studies on other traditional herbal medicines used in China}

Sinocalycanthus chinensis Cheng and S.Y. Chang, the only representative in the genus Sinocalycanthus in the family Calycanthaceae, is native to Zhejiang of China. This plant wears attractive cream and yellow semi-double flowers on the terminal twigs from May to June, and therefore, is cultivated as an ornamental tree in China [35]. The leaves of $S$. chinensis are used as a remedy for cold, cough, and wheeziness [36], while the flowers and roots of this plant have been used for the treatment of stomachache [37]. We 
examined the leaves of $S$. chinensis and isolated eight new triterpenes, sinocalycanchinensins A-H (31-38) (Fig. 8) [38]. Sinocalycanchinensin $\mathrm{F}(\mathbf{3 6})$ represents the first example of a 29-nor-2,3-seco-cycloartane triterpene. In contrast, 29-nor-3,4-seco-cycloartane triterpenes were reported only from the aerial part of Antirhea acutata (Rubiaceae) in previous researches [39, 40], and sinocalycanchinensins A-E, $\mathrm{G}$, and $\mathrm{H}$ appeared as the second examples of this type of triterpene. In addition, sinocalycanchinensin C (33) was the first example of a phytol ester of triterpene. Phytol, a component of chlorophylls, is known to be derived from a mevalonate-independent pathway, while cycloartanes are a metabolite of the mevalonate pathway. Sinocalycanchinen$\sin \mathrm{C}(\mathbf{3 3})$ is therefore a biosynthetically interesting molecule, as it is considered to be derived from the products of both mevalonate and mevalonate-independent pathways. Sinocalycanchinensins A-H (31-38) were evaluated for their cytotoxic activity against a panel of human cancer cell lines, KB, K562 (leukemia), and MCF7 cell lines, as well as multidrug-resistant (MDR) human cancer cell lines, including KB-C2 (colchicine-resistant KB) and K562/Adr (doxorubicin-resistant K562). Sinocalycanchinensin H (38) showed moderate cytotoxicities against all the tested cell lines, with $\mathrm{IC}_{50}$ values ranging from 14.8 to $18.8 \mu \mathrm{g} / \mathrm{mL}$, while the cytotoxicities of sinocalycanchinensin $\mathrm{G} \mathrm{(37)}$ were slightly less potent than those of $\mathbf{3 8}$. Sinocalycanchinensin F (36) also showed similar cytotoxicities against the tested cell lines except for MCF7. In contrast, sinocalycanchinen$\sin \mathrm{C}(\mathbf{3 3})$ did not exhibit cytotoxicity against all the tested cell lines $\left(\mathrm{IC}_{50}\right.$ values $\left.>100 \mu \mathrm{g} / \mathrm{mL}\right)$. Sinocalycanchinensin E (35) was also a weak cytotoxic compound, but it showed significantly enhanced cytotoxicity against KB-C2 cells in the presence of colchicine with an $\mathrm{IC}_{50}$ value of $1.5 \mu \mathrm{g} /$ $\mathrm{mL}$. Since colchicine had no effect on the growth of KB-C2 cells at this concentration level, $\mathbf{3 5}$ might show some MDRreversing effects. Overall, 3,4-seco-cycloartanes were less cytotoxic than the others.

Lonicera japonica Thunb. (Caprifoliaceae), also known as Japanese Honeysuckle, is a perennial twining woody vine native to the East Asia. This plant is often cultivated as an ornamental plant due to its attractive flowers and fragrances, while its flower buds have been used since early times for treatment of arthritis, diabetes mellitus, fever, infections, sores, and swelling [41]. The flower buds are also one of the major ingredients in Yin Qiao San, a most popular prescription in traditional Chinese medicine, used for common colds, including fever, headache, cough, thirst, and sore throat, and for influenza infection [42]. In an evaluation of the anti-influenza activity of Yin Qiao San in vitro, the $\mathrm{H}_{2} \mathrm{O}$ extract of Yin Qiao San inhibited all subtypes of influenza $\mathrm{A}, \mathrm{B}$, and $\mathrm{C}$ virus replications, and also exhibited inhibitory activity against an oseltamivir-resistant influenza A virus [43]. Therefore, chemical constituents of the flower buds of $L$. japonica were investigated, which resulted in
Fig. 8 The structures of sinocalycanchinensins A-H (31-38) isolated from Sinocalycanthus chinensis

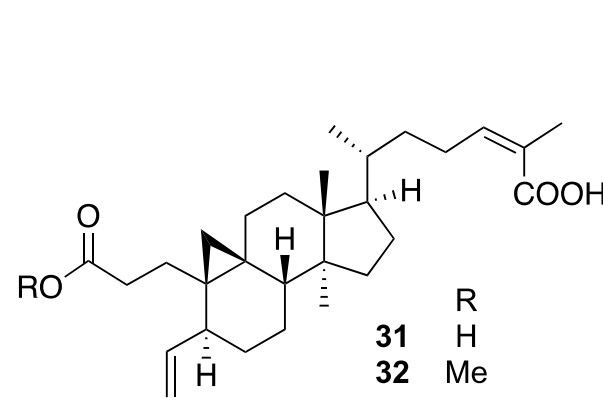

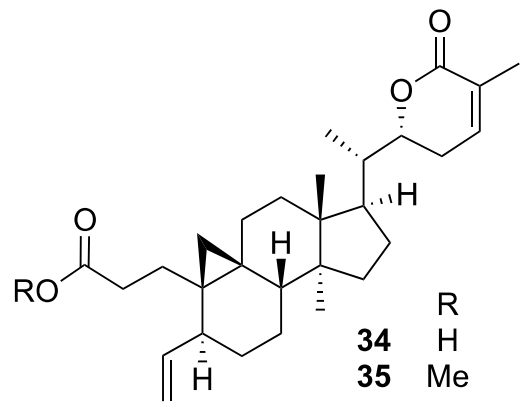

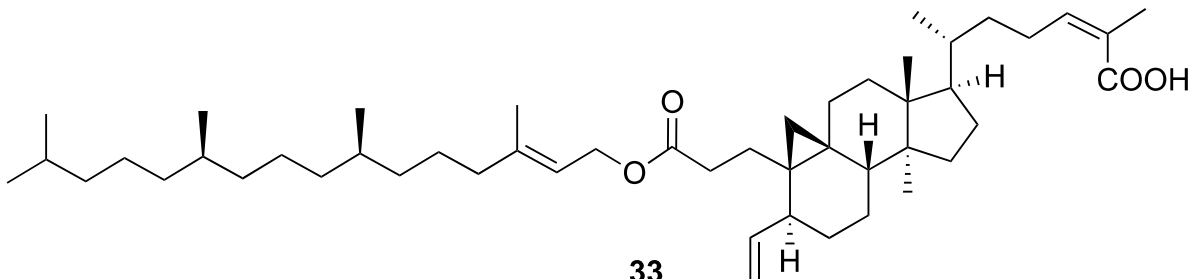

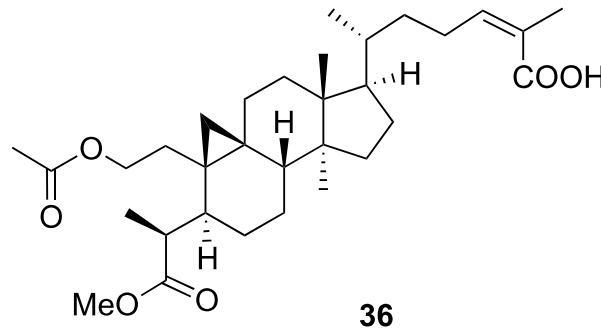

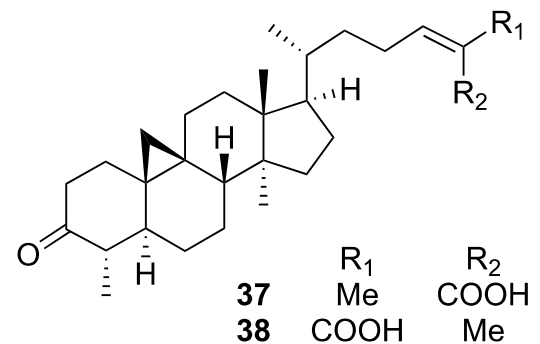


the isolation of four new secoiridoid glucoside derivatives (39-42) (Fig. 9) [44], together with seven known secoiridoid glucosides including secoxyloganin and dimethylsecologanoside. Lonicerjaponins A (39) and B (40) are structurally unique conjugates of a secoiridoid glucoside with a phenolic glucoside, in which a 6"-O-malonyl moiety of the phenolic glucoside was considered to be involved in conjugation. In contrast, $\mathbf{4 1}$ and $\mathbf{4 2}$ were secoiridoid glucosides coupled with nicotinic acid derivatives. The inhibitory effect on the growth of the A/PR/8/34 influenza virus was evaluated by plaque assay. Secoxyloganin and dimethylsecolologanoside inhibited influenza A virus replication by ca. $50 \%$ at noncytotoxic concentration $(100 \mu \mathrm{g} / \mathrm{mL})$, while a weak inhibitory activity was found in the other evaluated secoiridoid derivatives, except for $\mathbf{4 0}$. However, none of the secoiridoid derivatives displayed influenza A neuraminidase (NA) inhibitory activity.

Salviae miltiorrhizae Radix, the dried roots of S. miltiorrhiza Bge. (Lamiaceae) are one of the most popular traditional herbal medicines in Asian countries, and have been used extensively for the treatment of coronary artery disease, angina pectoris, myocardial infarction, cerebrovascular diseases, chronic renal failure, dysmenorrhea, and various types of hepatitis [45]. In our evaluation of the NA inhibitory effect of extracts from various herbal medicines, the $\mathrm{MeOH}$ extract from the dried roots of S. miltiorrhiza was found to exhibit an anti-NA activity. The $\mathrm{MeOH}$ extract was partitioned with $\mathrm{CHCl}_{3}$ and water, and the $\mathrm{CHCl}_{3}$-soluble material was found to show an NA inhibitory activity $\left(\mathrm{IC}_{50} 94.1 \mu \mathrm{g} / \mathrm{mL}\right.$ ). Repeated chromatographic separations of the $\mathrm{CHCl}_{3}$-soluble material afforded four new diterpenes, miltiorins A-D (43-46), together with eight known diterpenes including (+)-danshexinkun A (Fig. 10) [46]. Miltiorins A-C (43-45) are abietane diterpenes possessing a $2 \alpha$-acetoxy group and a 12 -hydroxy group in common, while 46 was a 11,12-seco-abietane diterpene with a $\gamma$-lactone ring. Miltiorin D (46) was the first example of the isolation of a 11,12-seco-abietane diterpene from natural<smiles>CC(=O)O[C@H]1C[C@H](C)[C@@H]2CCc3cc(C(C)C)c(O)cc3[C@@]2(C)C[C@@H]1OC(C)=O</smiles><smiles>CC(=O)OC1C[C@H](C)C2(C)C[C@H](C)C(=CC2=O)c2cc(C(C)C)c(O)cc21</smiles><smiles>CC(C)/C(=C/c1ccc2c3c1C(=O)OC3CCC2(C)C)C(=O)O</smiles>

Fig. 10 The structures of miltiorins A-D (43-46) isolated from Radix Salviae miltiorrhizae

sources. In an NA inhibitory assay for the isolated diterpenes, a norabietane diterpene, (+)-danshexinkun A, showed an NA inhibitory activity with an $\mathrm{IC}_{50}$ value of $39.5 \mu \mathrm{g} / \mathrm{mL}$, while no other diterpenes exhibited NA inhibitory activities.

\section{Phytochemical studies on traditional herbal medicines used in Mongolia}

Mongolia is located between China and Russia in the northern part of the Central Asian plateau, and has various climatic zones, including the northern taiga of Siberia, the steppe, and the deserts of Central Asia. Therefore, this country has a very diverse and distinctive flora, and many plants found there are unique. There are 3000 species of flowering plants, of which 975 species have been used traditionally in Mongolia and boundary countries [47]. The Mongolian medicine was influenced by Ayurveda and Tibetan medical systems. Mongolians have been using herbal remedies<smiles>C=CCc1ccc(OC2CC(OC(=O)CC=CC3C(C(=O)OC)=COC(O)C3(C=C)C=C)C(O)C(O)C(O)CO2)c(OC)c1</smiles>

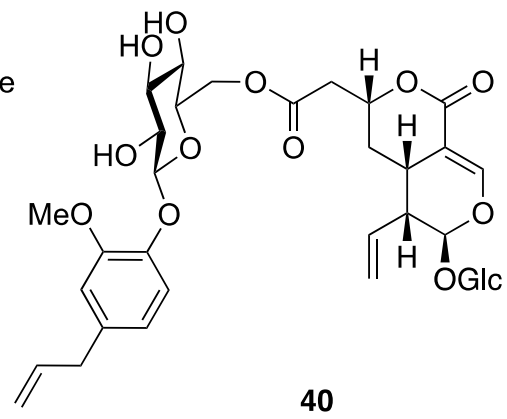<smiles>C=C[C@H]1[C@H](OC(C)=O)OC=C(C(=O)OC)[C@H]1/C=C/c1cncc(C(=O)O[Na])c1</smiles>

Fig. 9 The structures of lonicerjaponins A (39) and B (40) and pyridinium alkaloid coupled secoiridoid glucosides (41 and 42$)$ isolated from Lonicera japonica 
traditionally to prevent and cure the diseases of human and animals, and to improve animal productivity and fertility from ancient times [48]. About $72 \%$ of traditional Mongolian remedies were developed from plants, and over $28 \%$ were from animal or mineral sources [49], and various medicinal plants have been used in unique applications. We performed ethnobotanical and ethnopharmacological survey of Mongolian medicinal plants with researchers of Mongolian National University of Medical Sciences, Mongolia, based on the agreement between two universities.

Plants of the genus Linaria (Plantaginaceae), composed of about 200 species, are mainly distributed in the Mediterranean Basin and Eastern Asia, and have been used medicinally as tonics, antiscorbutics, and antidiabetics [50]. $L$. buriatica Turcz. is a perennial herb distributed in central and eastern Siberia, and Mongolia [51]. In our ethnobotanical and ethnopharmacological survey in Mongolia, we learned that the flowers of L. buriatica have been used as an herbal medicine for the treatment of fever and edema. Phytochemical study on the aerial parts of $L$. buriatica resulted in the isolation of four hitherto undescribed acylated iridoid glucosides, linaburiosides A-D (47-50), one undescribed iridoid, 7-deoxyiridolactonic acid (51) (Fig. 11) [52], and one known iridoid glucoside, iridolinarin C [53]. Linaburiosides A-D (47-50), as well as iridolinarin C, had an acyl moiety corresponding to $\mathbf{5 1}$. The absolute configuration of $\mathbf{5 1}$ was elucidated by application of the phenylglycine methyl ester (PGME) method, while those of $\mathbf{4 7 - 5 0}$ were assigned on the basis of chemical conversions, as well as application of the modified Mosher's method. The absolute configuration of iridolinarin $\mathrm{C}$ was also elucidated in this study. Linaburioside A (47), iridolinarin C, and 7-deoxyiridolactonic acid (51), along with iridoid glucoside moieties of $\mathbf{4 9}$ and iridolinarin C (antirrinoside and 10-deoxycatalpol, respectively), $2^{\prime}, 3^{\prime}: 4^{\prime}, 6^{\prime}$-diacetonide derivative of iridolinarin $C$, and the metanolysate of $\mathbf{5 1}$ (7-deoxyiridolactonic acid dimethyl ester) showed an inhibitory effect on IL- $1 \beta$ production from LPS-stimulated microglial cells. Linaburioside A (47) and iridolinarin $\mathrm{C}$ significantly inhibited IL- $1 \beta$ production by 74.8 and $81.7 \%$, respectively, at $100 \mu \mathrm{M}$ with no cytotoxicity against microglial cells. In addition, the $2^{\prime}, 3^{\prime}: 4^{\prime}, 6^{\prime}$-diacetonide derivative of iridolinarin $C$ suppressed IL- $1 \beta$ production by $91.3 \%$ at $100 \mu \mathrm{M}$ more potent than $\mathbf{4 7}$ and iridolinarin C. From these results, acylated iridoid glucosides, $\mathbf{4 7}$ and iridolinarin $\mathrm{C}$, appear to be a potential lead of therapeutic agent for neuroinflammation-related disease.

Lophanthus plants (Lamiaceae), composed of 23 species of perennial herbs or sub-shrubs, are distributed over alpine in Turkey, Iran, Afghanistan, central Asia, China, and Mongolia. Although the genus Lophanthus is considered to be very closely related to the well-studied genus Nepeta [54, 55], we learned in our survey that the aerial parts of $L$. chinensis Benth. have been used for the treatment of dizziness,

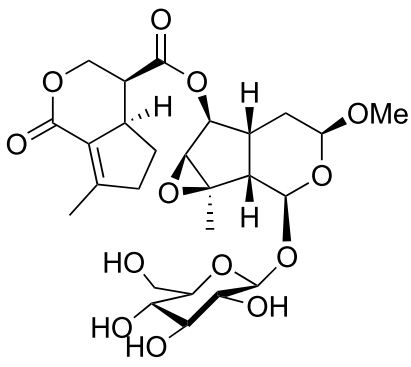

47

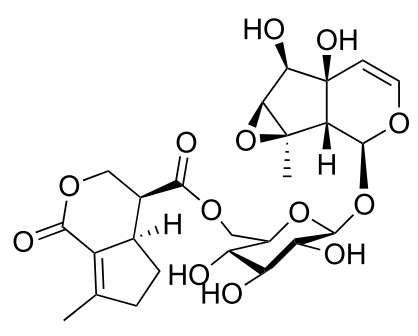

50

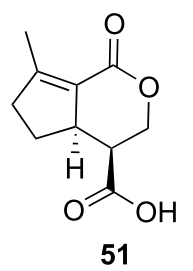

Fig. 11 The structures of linaburiosides A-D (47-50), 7-deoxyiridolactonic acid (51), and iridolinarin $\mathrm{C}$ isolated from Linaria buriatica

fevers, and inflammatory diseases in Mongolia. Our chemical study on the aerial parts of L. chinensis afforded five new abietane diterpenes, lophachinins A-E (52-56), together with eleven known related diterpenes (Fig. 12) [56]. Based on a traditional usage of L. chinensis in Mongolia, all the isolated diterpenes were evaluated for their anti-inflammatory activity on microglial cells. Thus, lophachinins A (52) and B (53) demonstrated moderate inhibitory effects on IL- $1 \beta$ production at $100 \mu \mathrm{M}$ by 81.6 and $48.2 \%$, respectively, from LPS-treated microglial cells without cytotoxicity, while some known diterpenes also exhibited inhibitory effects comparable to $\mathbf{5 2}$ and $\mathbf{5 3}$.

Gentiana algida Pall. is a perennial plant distributed in North Asia and west area of North America. In Mongolia, the aerial parts of G. algida have been used for the treatment of throat illness caused by fever, lung disorders, liver disorders, and bile disorder [57]. Constituents of the aerial parts of G. algida were investigated to give a structurally unique secoiridoid glucoside, algiolide A (57). The structure of 57 was elucidated on the basis of spectroscopic analysis and chemical conversion as well as DFT calculation of ${ }^{13} \mathrm{C}$ NMR and TDDFT calculation of ECD spectra [58]. Although a variety of secoiridoids were isolated from Gentiana plants, 


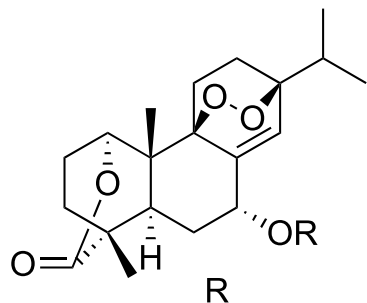

$52 \mathrm{H}$

$53 \mathrm{Me}$<smiles>CC(C)c1ccc2c(c1)C(=O)C[C@H]1[C@@H](C)CC[C@@H](O)[C@]21C</smiles>

55<smiles>CC(C)c1ccc2c(c1)[C@H](O)C[C@H]1[C@@H](C)CC[C@@H](O)[C@@]21C</smiles>

54

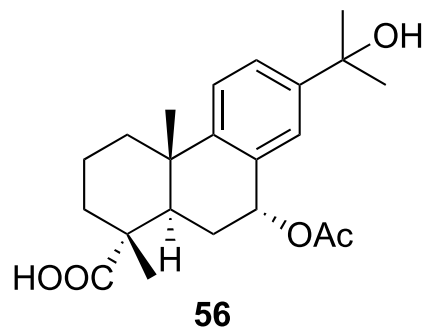

Fig. 12 The structures of lophachinins A-E (52-56) isolated from Lophanthus chinensis

57 has a novel skeleton consisting of fused $\alpha, \beta$-unsaturated$\delta$-lactone and cyclopentene rings. Algiolide A (57) was considered to be derived from gentiopicroside, a major constituent of the flower of G. algida (Scheme 1). Thus, epoxidation of the double bond and cleavage of acetal, and intramolecular cyclization of gentiopicroside give a plausible intermediate $(\mathbf{X})$, whose epoxidation followed by dehydration and reduction of the double bond yields algiolide $\mathrm{A}(\mathbf{5 7})$.<smiles>O=C1OCCC2=C1CC(CO)C2COC1CCCCC1</smiles>

57

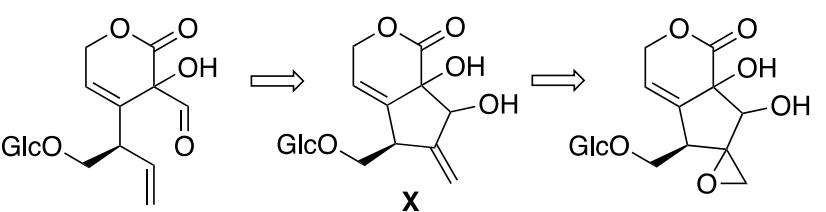
||<smiles>C=CC(COC(C)=O)C1=CCOC(=O)C1(O)C=C</smiles><smiles>C=CC1C2=CCOC(=O)C23OC3OC1[O+]</smiles><smiles>C=CC=C</smiles><smiles>C=CC1C2=CCOC(=O)C2=COC1OC(C)=O</smiles>

gentiopicroside
Scheme 1 The structure of algiolide A (57) isolated from Gentiana algida and its plausible biogenetic pathway from gentiopicroside
Plants of the genus Gentianella (Gentianaceae) comprising about 250 species, of which many have a bitter taste, are distributed in temperate regions throughout the world [59]. Gentianella amarella ssp. acuta (synonym Gentiana acuta) is an annual herb distributed in East Asia, Siberia, and North America, and has been used as a traditional herbal medicine for the treatment of headache, fever, hepatitis, and gallbladder disorders in Mongolia [60]. The phytochemical investigation of the aerial parts of $G$. amarella ssp. acuta gave two tetrahydroxanthones, $1,3,5 S, 8 S$-tetrahydroxy-5,6,7,8tetrahydroxanthone (58) and 1,3,5R,8S-tetrahydroxy-5,6,7,8tetrahydroxanthone (59), and six new tetrahydroxanthone glycosides, amarellins A-F (60-65) [61]. Yang et al. also isolated 60-65 from the same plant materials, and evaluated for their inhibitory effects on the isolated intestinal smooth muscle contractions. All the evaluated compounds significantly reduced on contraction tension, while no significant change was observed for the isolated intestinal tissue contraction frequency [62] (Fig. 13).

Inonotus obliquus, a fungus belonging to the Hymenochaetaceae family [63], is parasitic on birch trees found in Eastern and Northern Europe, Russia, Northern Asia, and in North America and Canada. The sclerotium of I. obliquus, also called Chaga mushrooms, has been used to treat cancer in Russia and Western Siberia for centuries. Although most scientific studies on Chaga mushrooms have been focused on their antitumor properties, we learned that the decoctions of Chaga mushrooms have been used traditionally in Mongolia as a shampoo for maintaining healthy hair. The information prompted us to study Chaga mushrooms for hair growth-promoting effects. Separation of the $80 \% \mathrm{EtOH}$ aq. extract of Chaga mushrooms guided by a proproliferative activity on human follicle dermal papilla cells (HFDPCs) gave five lanostane-type triterpenes, lanosterol (66), lanost8,24-diene-3 $\beta$-ol-22-al (67), inotodiol (68), lanost-8,24diene-3 $\beta, 21$-diol (69), and trametenolic acid (70). Proliferation rates of cells treated with $\mathbf{6 9}$ and $\mathbf{7 0}$ at $1.25 \mu \mathrm{M}$ and with 69 at $5 \mu \mathrm{M}$ were higher than those treated with $80 \mu \mathrm{M}$

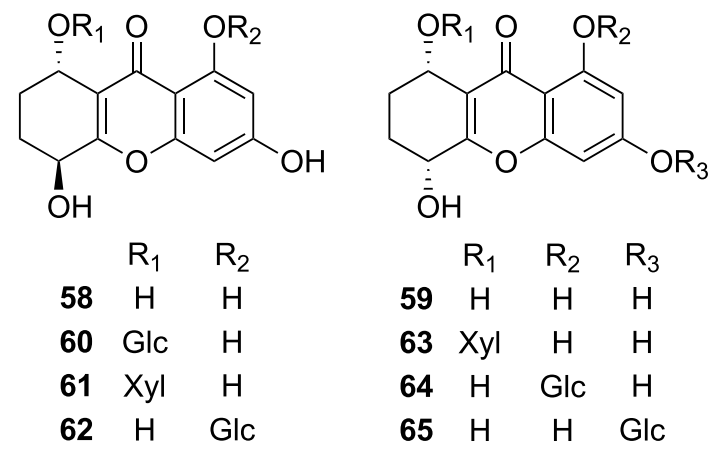

Fig. 13 The structures of amarellins A-F (60-65) and their aglycones (58 and 59) isolated from Gentianella amarella ssp. acuta 
of minoxidil. Compounds 66 and 68 showed proproliferative effects at 0.31 and $20 \mu \mathrm{M}$, respectively, comparable to $80 \mu \mathrm{M}$ of minoxidil, whereas 68 exhibited cytotoxicity at a higher concentration [64]. In contrast, $\mathbf{6 7}$ showed proproliferative effects at lower concentrations of 0.02 and $0.08 \mu \mathrm{M}$ more potent than those treated with $80 \mu \mathrm{M}$ of minoxidil, although proproliferative effects were not observed at concentrations over $0.31 \mu \mathrm{M}$. Thus, $\mathbf{6 6}-\mathbf{7 0}$ appeared as potential candidates of new agents possibly used for hair care with a stimulative effect on hair growth. It should be noted that crude fractions obtained from Chaga mushroom extracts did not show inhibitory activities on testosterone $5 \alpha$-reductase and androgen receptor, whereas several steroid derivatives with such activities are used for the treatment of alopecia [65]. This result suggested that these triterpenes have a mode of action related to hair growth different from those of steroid derivatives. The results of this study suggest that Chaga mushroom extracts could be utilized to an ingredient of a hair care product for the treatment of hair loss, and that triterpenes from Chaga mushrooms could be potential leads of therapeutic agents for promoting hair growth (Fig. 14).

\section{Phytochemical studies on traditional herbal medicines used in Uzbekistan}

Uzbekistan, one of the republics in Central Asia, has rich source of plants. The flora of Uzbekistan includes more than 4500 species of vascular plants, of which $20 \%$ are endemic to Uzbekistan. Many of them are globally important but are endangered. The floristic data for several regions of Uzbekistan are still imperfect, and botanical studies are continuing. In addition, the phytochemical study and biological activity evaluation of these plants are still not fully conducted, and they may contain pharmaceutically potential constituents [66]. Characteristic herbal medicines only found in Uzbekistan have been used traditionally, since

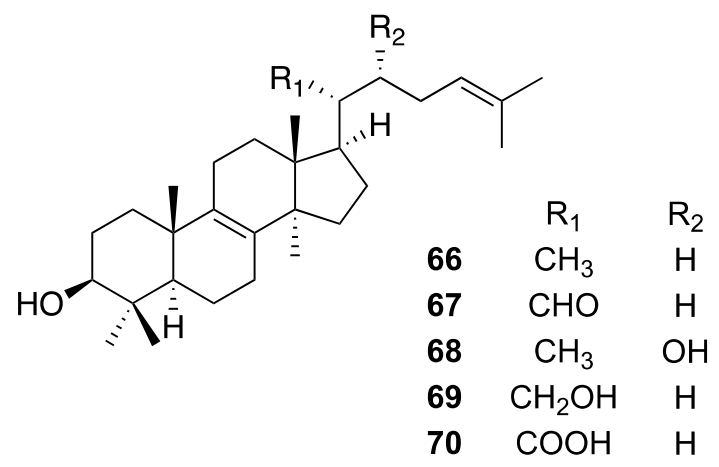

Fig. 14 The structures of lanostane type triterpenes $(\mathbf{6 6 - 7 0})$ as proproliferative agents on HFDPCs from the sclerotium of Inonotus obliquus the number of endemic plants in this area is significantly higher than those of the other areas as described above. In addition, seven major ethnic populations with ancestors in Kazakhstan, Turkmenistan, Tajikistan, Afghanistan, Russia, Uzbekistan, and Kyrgyzstan, live in Uzbekistan, and therefore, the wide spectrum of medicinal plant utilizations are found based on ethnic differences [67]. About 70\% of Uzbek households use traditional herbal medicines in their daily lives [68]. Our ethnopharmacological survey of Uzbek traditional herbal medicines and their phytochemical studies have been performing based on ethnopharmacological information exchanges with the researchers at Institute of Botany and Botanical Garden, Academy of Science of Uzbekistan and Institute of the Chemistry of Plant Substances, Academy Sciences of the Republic of Uzbekistan.

About 100 Lamiaceous plants are considered to be native of Uzbekistan, while plants of the genus Perovskia, a small group of the Lamiaceae family, are aromatic shrubs growing in arid region of Central Asia [69]. The aerial parts of P. scrophulariifolia have been used as a traditional herbal medicine to treat dermatitis and human intestinal parasites in Uzbekistan. The aerial parts of $P$. scrophulariifolia have been investigated, which resulted in the isolation of two novel terpenoids, perovsfolins A (71) and B (72) [70], and two new 20-norabietane diterpenes, perovsfolins $\mathrm{C}(\mathbf{7 3})$ and D (74) [71] (Fig. 15), together with 13 known diterpenes including 7-O-methylrosmanol, carnosol, and demethylsalvicanol quinone, as well as methylrosmarinate. Perovsfolins A (71) and B (72) possessed a $\mathrm{C}_{28}$ terpenoid moiety with unprecedented 6/8/6/6/6 pentacyclic carbon skeleton, which were presumed to be generated by condensation of a 20-norabietane diterpene and methyl rosmarinate, where spontaneous (non-enzymatic) reactions may be involved. Perovsfolins A-D (71-74) and known diterpenes were evaluated for their inhibitory activity on IL- $1 \beta$ production from LPS-stimulated microglial cells as part of our search for natural products to be a potential lead of therapeutic agent for neuroinflammation-related disease. Thus, carnosol potently inhibited IL-1 $\beta$ production by $96 \%$ from LPS-stimulated microglial cells at $12.5 \mu \mathrm{M}$ without cytotoxicity (cell viability $>80 \%$ ) against microglial cells. Columbaridione, 7-O-methylrosmanol, and demethylsalvicanol quinone also showed inhibitory activities ( $45.9 \%$ at $6.25 \mu \mathrm{M}, 41.5 \%$ at $12.5 \mu \mathrm{M}$, and $44.8 \%$ at $25 \mu \mathrm{M}$, respectively) with no cytotoxicity. Perovsfolin B (72) was also found to be a weak inhibitor of IL- $1 \beta$ production from LPS-stimulated microglial cells $(24.3 \%$ at $25 \mu \mathrm{M})$ without cytotoxicity against microglial cells (cell viability $>80 \%$ ).

The genus Ferula, one of the largest genus of the Apiaceae (Umbelliferae) family, has about 170 species distributed from Central Asia, throughout the Mediterranean region to northern Africa. Several species of this genus have been used in ethno-medicine for the treatment of digestive disorders, headache, dizziness, arthritis, rheumatism, and 
Fig. 15 The structures of perovsfolins A-D (71-74) and carnosol isolated from Perovskia scrophulariifolia

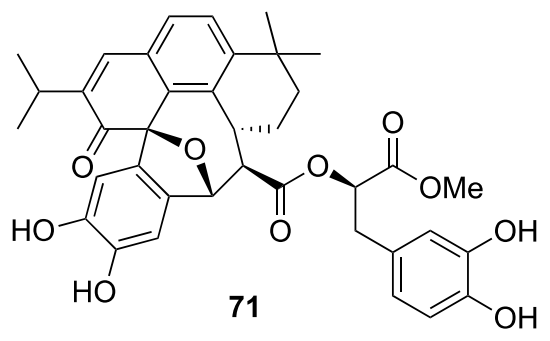<smiles>[R2]C(=O)[C@H](Cc1ccc(O)c(O)c1)OC(=O)[C@@H]1[C@@H]2O[C@]3(C(=O)C(C(C)C)=Cc4ccc5c(c43)[C@@H]1CCC5(C)C)c1cc(O)c(O)cc12</smiles><smiles>CC(C)c1cc2c3c(c1O)O[C@H]1CCC(C)(C)[C@@H](CC2)[C@]31C</smiles>

73<smiles>CC(C)c1cc2c(c(O)c1O)[C@]1(C(=O)O)CCC[C@@H](C)[C@H]1CC2OC(=O)O</smiles>

toothache and as tranquilizers in Uzbekistan. The roots of F. varia (Shrenk) Trautv. have been used traditionally to treat fever and intestinal parasites and as a mouth rinse. The $\mathrm{MeOH}$ extract from the roots of $F$. varia was partitioned with EtOAc and $\mathrm{H}_{2} \mathrm{O}$. Repeated chromatographic separations of the EtOAc-soluble materials gave six new (75-80) and five known sesquiterpene lactones [72], while the $\mathrm{H}_{2} \mathrm{O}$-soluble materials was chromatographed to give fifteen new sesquiterpene lactone glycosides, including twelve new eudesmane, two new guaiane, and one new germacrane type sesquiterpene lactone glucosides [73, 74]. All the isolated compounds had a cis-fused $\gamma$-lactone ring at C-6 and C-7, which was also seen in sesquiterpene lactones isolated from the EtOAc-soluble fraction. $F$. varia characteristically contained sesquiterpene lactone derivatives with a $c i s$-fused $\gamma$-lactone. The sesquiterpenes isolated from the EtOAc-soluble fraction of $F$. varia were evaluated for their cytotoxic activity against human tumor cell lines, including MDR human cancer cell lines KB-C2 and K562/Adr. Compound 78 was significantly cytotoxicity against $\mathrm{KB}-\mathrm{C} 2$ cells with an $\mathrm{IC}_{50}$ value of $15.7 \mu \mathrm{g} / \mathrm{mL}$, while doxorubicin, tested as a positive control, was nontoxic against the resistant cell lines ( $>100 \mu \mathrm{g} /$ $\mathrm{mL}$ ). Cytotoxicity of $\mathbf{7 8}$ against KB-C2 was selective, since it was 4.6 times more potent than that $\left(\mathrm{IC}_{50} 72.8 \mu \mathrm{g} / \mathrm{mL}\right.$ ) against sensitive cells (KB). Compound $\mathbf{7 8}$ was also slightly more cytotoxic against K562/Adr cells than against K562 cells. Compounds 75, 77, and 79, and $8 \alpha$-angeloyloxy10ß-hydroxy-3-en-6,12-olide were nontoxic against all the tested cell lines $\left(\mathrm{IC}_{50}\right.$ values were $>100 \mu \mathrm{g} / \mathrm{mL}$ ), whereas they showed moderate cytotoxicity against KB-C2 cells with $\mathrm{IC}_{50}$ values ranging from 25.4 to $67.8 \mu \mathrm{g} / \mathrm{mL}$ in the presence of $2.5 \mu \mathrm{M}$ colchicine, indicating that these compounds have some MDR-reversing effect. Since MDR inhibitors are known to inhibit the efflux of anticancer drugs by interfering with P-glycoprotein (P-gp) function, compounds $\mathbf{7 7}$ and $\mathbf{7 8}$, and $8 \alpha$-angeloyloxy-10 $\beta$-hydroxy-3-en-6,12-olide were also examined for their effects on P-gp function in KB-C2 cells. Compounds $\mathbf{7 7}$ and 78, and $8 \alpha$-angeloyloxy-10 $\beta$-hydroxy3-en-6,12-olide increased rhodamine 123 accumulation to 169 and 134 , and $114 \%$, respectively, at $50 \mu \mathrm{M}$, while verapamil, a modulator of P-gp function, showed an increase of rhodamine 123 accumulation by $32 \%$ at $2 \mu \mathrm{M}$ and by $80 \%$ at $5 \mu \mathrm{M}$. Since these sesquiterpenes had no effect on the efflux of rhodamine 123 from KB-C2 cells by P-gp, $\mathbf{7 7}$ and $\mathbf{7 8}$ were considered to change the toxicity of colchicine against KB-C2 cells by other than interfering with P-gp function (Fig. 16).

Mediasia macrophylla (Regel ex Schmalh.) Pimenov (Apiaceae) is an Uzbek medicinal plant, whose aerial parts have been used traditionally as a perfume, an appetite<smiles>[R]C[C@]1(O)C(=O)O[C@H]2[C@@H]3C(=C)C=C[C@H](O[GaH2])[C@@]3(C)CC[C@H]21</smiles>
R $75 \quad \mathrm{H}$ 76 OAng

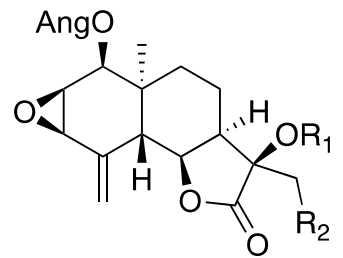
$\mathrm{R}_{1} \quad \mathrm{R}_{2}$ $\begin{array}{lll}77 & \mathrm{H} & \text { OAng } \\ 78 & \text { Ang } & \mathrm{H}\end{array}$<smiles>C/C=C(/C)C(=O)C[13CH3]</smiles>

79<smiles>CO[C@H]1CC(C)=C2C(=O)C=C(C)[C@@H]2[C@H]2OC(=O)[C@](C)(O)[C@@H]12</smiles>

Fig. 16 The structures of acylated sesquiterpenes (75-80) isolated from Ferula varia 
enhancer, a natural preservative, and for treatment of rheumatism, nephritis, eczema, herpes, and injury [75]. This plant is also used in combination with four other medicinal plants, Ziziphora pedicellate (Lamiaceae), Urtica dioica (Urticaceae), Codonopsis clematidea (Capmpanulaceae), and Origanum tyttanthum (Lamiaceae), for the improvement of hepatic function in Uzbekistan. Our phytochemical study on the aerial parts of M. macrophylla furnished five new polyacetylenic glucosides (81-85) (Fig. 17) [76]. Polyacetylenic compounds are widely distributed especially in the families Apiaceae, Asteraceae, and Araliaceae, and fungi of the group Basidiomycetes. Among these, Apiaceous plants mainly contain $\mathrm{C}_{17}$-polyacetylenic compounds [77]. By contrast, $\mathrm{C}_{10^{-}}$and $\mathrm{C}_{14}$-polyacetylenic glycosides have been reported only from a few members of the Asteraceae and Campanulaceae families [78]. Compounds 82-85 appear to be the first example of $\mathrm{C}_{10}$-polyacetylenic glucosides from an Apiaceous plant. In addition, compound $\mathbf{8 1}$ was the first example of a polyacetylen derivative possessing an $\alpha$-pyrone moiety from natural sources. Later, Jelodarian et al. reported the isolation of polyacetylene containing an $\alpha$-pyrone moiety from Echinophora cinerea in 2017 [79]. The co-occurrence of $\mathrm{C}_{10}$-polyacetylenic glucosides (82-85) and a $\mathrm{C}_{14}$-polyacetylenic glucoside possessing an $\alpha$-pyrone moiety (81) suggested that the $\mathrm{C}_{14}$-polyacetylenic unit of $\mathbf{8 1}$ may be derived from a $\mathrm{C}_{10}$-polyacetylenic compound, such as the aglycone of $\mathbf{8 2}$, by condensation of the additional two malonyl units, followed by oxidation. Compound 84 as well as its aglycone were later isolated from Artemisia capillaris

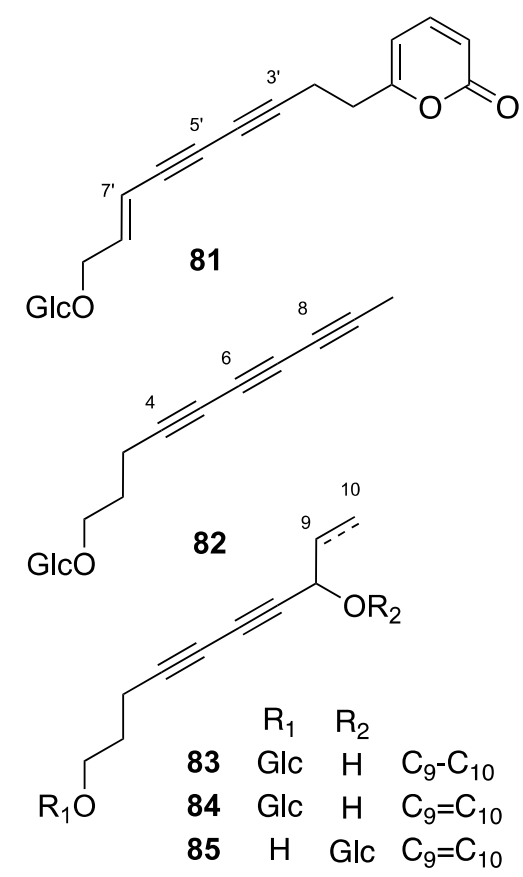

Fig. 17 The structures of polyacetylenic glucosides $(\mathbf{8 1}-\mathbf{8 5})$ isolated from Mediasia macrophylla
(Apiaceae) by Geng et al., and the $8 S$-configuration of aglycone was deduced from its specific rotation. In addition, an inhibitory activity of $\mathbf{8 4}$ against HBV DNA replication with an $\mathrm{IC}_{50}$ value of $11.0 \mu \mathrm{g} / \mathrm{mL}(\mathrm{SI}=79.3)$ was also reported [80].

Paeoniae Radix, one of the most important traditional herbal medicines, has been used for remedies for gynecological problems, cramps, pain, and dizziness in Japan and China. A variety of paeoniflorin-related monoterpene glycosides and tannins were shown to be characteristic metabolites of Paeonia plants (Paeoniaceae) [81]. P. hybrida Pall. is a traditional herbal medicine used in Uzbekistan, and a water decoction of its roots has been used to treat nerve disease [82]. We examined phytochemically on the roots of $P$. hybrida to isolate six new monoterpene glycosides including paeonihybridin (86) and paeobrin (87) as well as fourteen known compounds (Fig. 18) [83]. Paeonihybridin (86) had a unique hybrid structure consisting of paeoniflorin and paeonovicinoside. Paeobrin (87), possessing a novel carbon framework, was considered to be derived from paeoniflorin through the similar process for the production of lactiflorin [84] as shown in Scheme 2. Thus, an oxacyclic ring-opening of paeoniflorin followed by successive cationic 1,2-carbon shifts yield a plausible biogenetic intermediate $(\mathbf{Y})$, which produces lactiflorin or paeobrin depending on whether C-1 forms an ether bond with $\mathrm{C}-2$ ' in the glucosyl moiety or $\mathrm{C}-3$, respectively. Later, $\mathrm{Ha}$ et al. reported the isolation of hydroxypaeobrinone, whose structure is closely related to 87, from $P$. suffruticosa [85].

Juniperus plants (Cupressaceae), including about 70 species, are evergreen shrubs or trees, and are widely distributed over the northern hemisphere. Some Juniperus species have
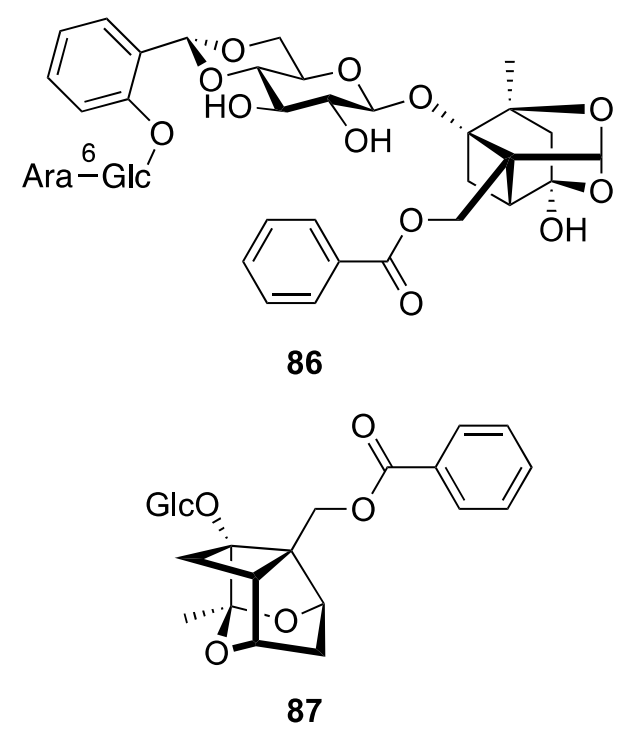

Fig. 18 The structures of paeonihybridin (86) and paeobrin (87) isolated from Paeonia hybrida 
Scheme 2 Possible biosynthetic pathway of paeobrin (87), hydroxypaeobrinone, and lactiflorin from paeoniflorin
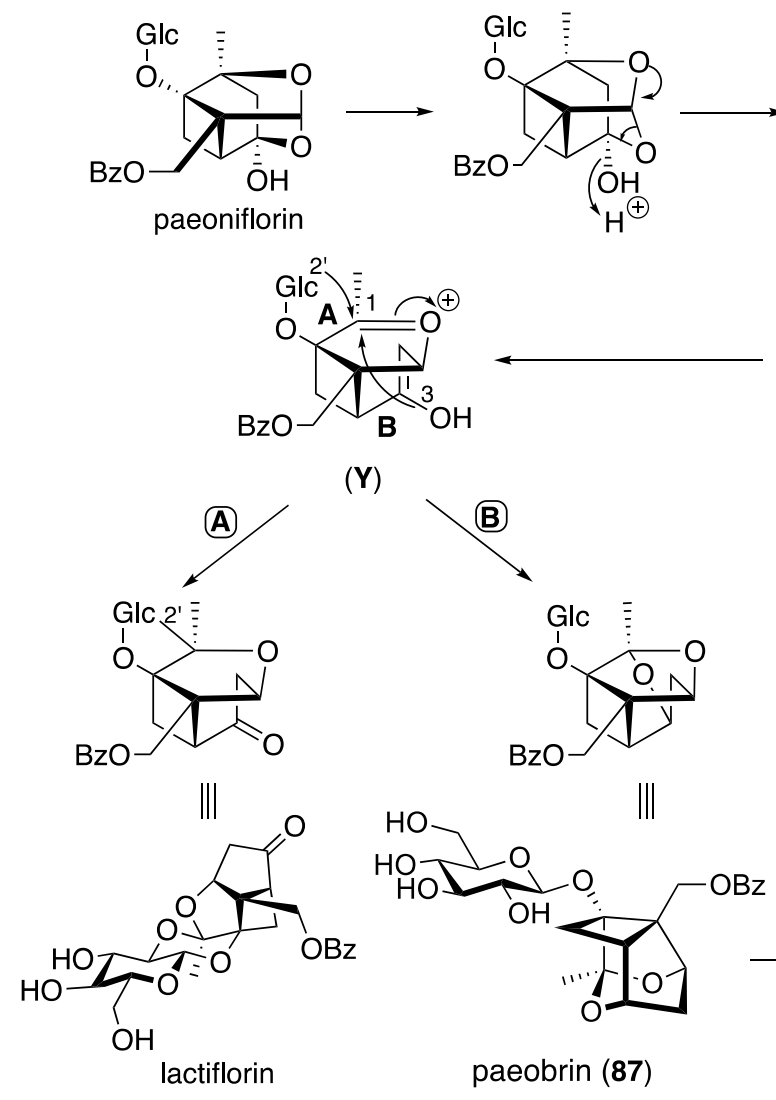

(Y)
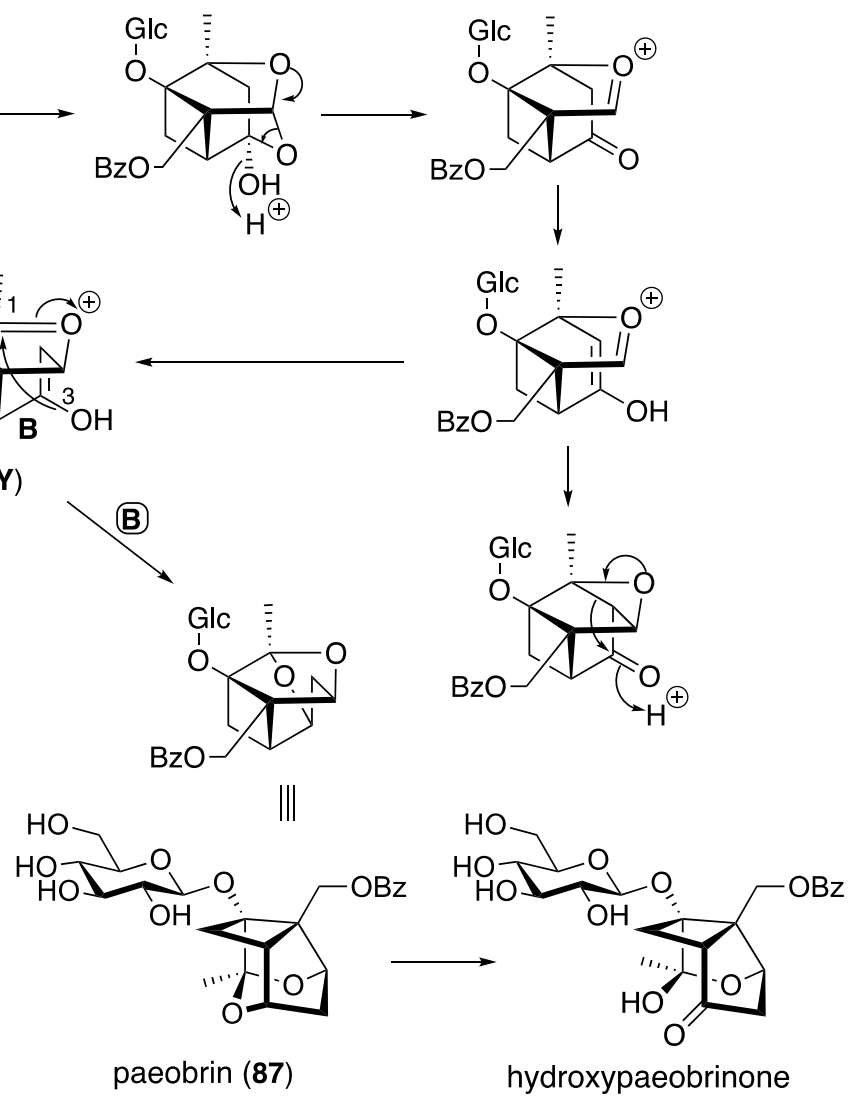

been traditionally used in medicinal purposes; J. communis L. has been used for the treatment of tuberculosis, while $J$. oxycedrus L. has been used in Turkey as an ethnic herbal medicine for the treatment of diabetes [86]. J. polycarpus var. seravschanica (syn. J. seravschanica) is an evergreen tree indigenous to the mountains of Central Asia. Its seed decoction has been used as an herbal medicine for kidney diseases, and as a diuretic and abortive in Uzbekistan [87, 88]. Repeated chromatographic separations of the extract of the air-dried fruits of $J$. polycarpus var. seravschanica afforded two new sesquiterpenes (88 and $\mathbf{8 9}$ ), and four new diterpenes (90-93), together with nine known compounds including cedrol and sugiol (Fig. 19) [89]. In evaluation of an antimalarial activity against three Plasmodium falciparum clones, D6, TM91C235, and W2, cedrol and sugiol demonstrated weak activities against $\mathrm{D} 6$ clone $\left(\mathrm{IC}_{50}\right.$ values of 0.059 and $0.47 \mu \mathrm{g} / \mathrm{mL}$, respectively), TM91C235 clone $(0.30$ and $1.0 \mu \mathrm{g} / \mathrm{mL})$, TM91C235 clone $(0.30$ and $1.0 \mu \mathrm{g} /$ $\mathrm{mL})$, and against $\mathrm{W} 2$ clone $(0.22$ and $0.41 \mu \mathrm{g} / \mathrm{mL})$, while the other tested compounds did not show significant antimalarial activity.

Plants of the genus Codonopsis (Campanulaceae), commonly called as bonnet bellflower, are perennial herbs endemic to East Asia. The roots of several Codonopsis species have been used in Chinese traditional medicine as Codonopsis Radix to treat appetite loss, diarrhea, and vomiting.<smiles>C=C1CC[C@@H](O)[C@]2(C)CC[C@](O)(C(C)(C)O)C[C@@H]12</smiles>

88<smiles>[R]C1CCC[C@@]2(C)c3ccc(C(C)(C)O)cc3[C@@H](O)C[C@@H]12</smiles>

$\begin{array}{ll}90 & \mathrm{COOH} \\ 91 & \mathrm{CH}_{2} \mathrm{OH}\end{array}$<smiles>CC1=CC[C@@H](O)[C@]2(C)CC[C@](O)(C(C)(C)O)CC12</smiles>

89<smiles>[R][C@]1([2H])CCC[C@]2(C)[C@H]3CCC(=O)C=C3[C@@H](O)C[C@H]12</smiles>

$\mathrm{R}$

$92 \mathrm{CH}_{2} \mathrm{OH}$

$93 \mathrm{COOH}$
Fig. 19 The structures of new sesquiterpenes ( $\mathbf{8 8}$ and $\mathbf{8 9}$ ) and diterpenes (90-93) isolated from Juniperus polycarpus var. seravschanica

In contrast, the aerial parts of $C$. clematidea (Schrenk) Clark have been used in Uzbekistan to treat liver disease, hepatitis, and jaundice. This plant is also used in combination with four other medicinal plants to improve hepatic function as described above. Examination of the aerial parts of $C$. 
clematidea resulted in the isolation of a new codonopsinerelated alkaloid, codonopsinol (94), together with thirteen known compounds [90]. Codonopsinol (94) being structurally related to radicamine A, an $\alpha$-glucosidase inhibitor isolated from Lobelia chinensis (Campanulaceae) [91], was expected to have similar activity. Synthetic study of a series of 2-aryl polyhydroxylated pyrrolidines, including (-)-94 and (-)-radicamine $\mathrm{A}$, as well as their evaluation of inhibitory activity against $\alpha$-glucosidase was carried out by Cheng et al. (-)-Codonopsinol (94) was shown to have an inhibitory activity against $\alpha$-glucosidase of yeast and Bacillus stearothermophilus lyoph, although its potency was about half of radicamine A [92] (Fig. 20).

\section{Phytochemical studies on traditional herbal medicines used in Bangladesh}

Bangladesh, a subtropical country of Indian sub-continent, possess a great diversity in plants, being estimated to have about 7000 endemic plant species, including bryophytes, pteridophytes, gymnosperms, and angiosperms [93]. There are approximately 5,000 angiosperms, belonging to about 200 families, distributed of which 500 have been used in the traditional medical systems including Ayurvedic and Unani for the treatment of different types of diseases [94]. In addition, Bangladesh has the Board of Unani and Ayurvedic Systems of Medicine, which arrange for the standardization of Unani and Ayurvedic systems of medicine, and these established are widely used in this country [95]. Besides these medical systems, traditional medicinal practitioners, known variously as Kavirajes or Vaidyas, in Bangladesh have been used their own herbal medicines [96]. We have been studying traditional herbal medicines for searching new drug<smiles>COc1ccc([C@H]2C(O)[C@@H](O)C(CO)N2C)cc1OC</smiles><smiles>COc1ccc(C2NC(CO)[C@@H](O)C2O)cc1O</smiles>

radicamine $\mathrm{A}$

Fig. 20 The structures of codonopsinol (94) isolated from Codonopsis clematidea and radicamine A

leads based on ethnopharmacological information exchanges with the researchers of Jahangirnagar University.
Azadirachta indica A. Juss (Meliaceae), also known well as neem tree, is widely distributed in the tropical zones of Africa, South Asia, and India. This plant has been used as a traditional herbal medicine in India for more than 2000 years, because of its valuable biological activities, especially its anti-inflammatory, anti-ulcer, antimalarial, antibacterial and antioxidant activities. A. indica is also known to contain an antifeedant limonoid, azadirachtin A $[97,98]$. Our phytochemical study on the fruits of A. indica furnished four new molecules, indicalilacols A-D (95-96) (Fig. 21), which were assigned as a $19(10 \rightarrow 9 \beta)$ abeotirucallane triterpene (95), tirucallane triterpenes (96 and 97), and a euphane triterpene (98), as well as three known tirucallane type triterpenoids, meliasenin S, meliantriol, and melianodiol [99]. Cytotoxicity against two human tumor cell lines (KB and MCF7) and against one MDR cancer cell line (KB-C2) was evaluated for the isolated compounds, together with meliasenin $\mathrm{T}$, prepared from meliantriol. Indicalilacol (96), meliantriol, melianodiol, and meliasenin $\mathrm{T}$ were moderately cytotoxic against all the tested cell lines with $\mathrm{IC}_{50}$ values ranging from 9.04 to $25.7 \mu \mathrm{g} / \mathrm{mL}$, while meliasenin $\mathrm{S}$ showed no cytotoxicity against any of the tested cancer cell

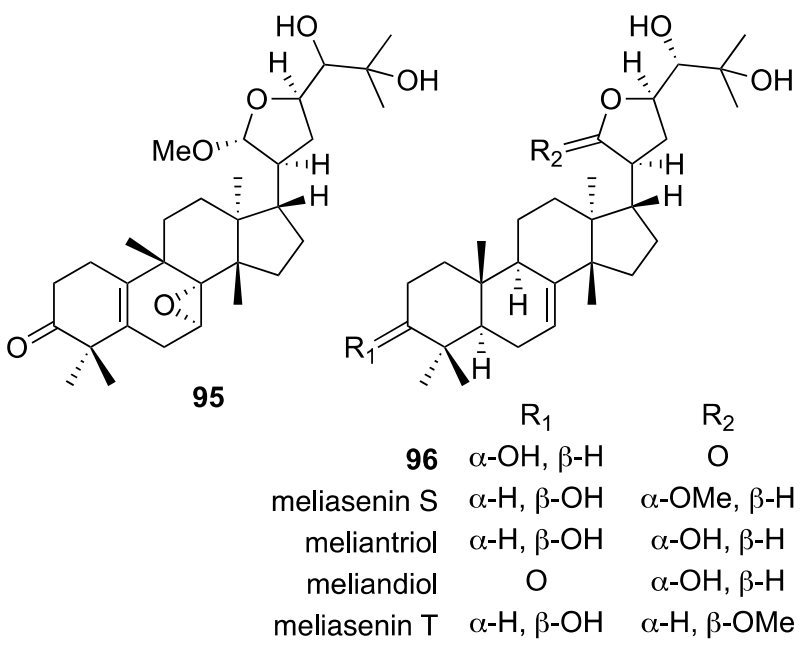

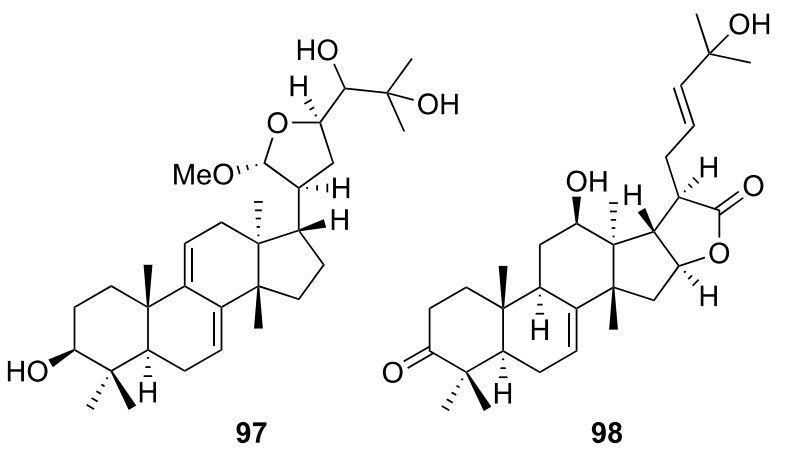

Fig. 21 The structures of indicalilacols A-D (95-98), meliasenin S, meliantriol, and melianodiol isolated from Azadirachta indica, and meliasenin $\mathrm{T}$ 
lines. However, meliasenin S might have an MDR-reversal effect, since it showed cytotoxicity against KB-C2 cells in the presence of $2.5 \mu \mathrm{M}$ colchicine with an $\mathrm{IC}_{50}$ value of $6.48 \mu \mathrm{g} / \mathrm{mL}$. In contrast, meliasenin $\mathrm{T}$, the $\mathrm{C}-21$ epimer of meliasenin $\mathrm{S}$, only showed a week cytotoxicity against $\mathrm{KB}-\mathrm{C} 2$ cells in the presence of $2.5 \mu \mathrm{M}$ colchicine, and therefore, the stereochemistry of C-21 might play an important role.

Tephrosia purpurea (L.) Pers. (Fabaceae), also commonly known as "sarpunkha" and "wild indigo", is a perennial herb widely grown in India, Ceylon, Mauritius, tropical Africa and subtropical regions. Various parts of this plant have been used as tonic, laxative, and diuretic as well as for the treatment of bronchitis, bilious febrile attack, boils, pimples, diarrhea, gonorrhea, rheumatism, and disease of heart, spleen, and blood in Ayurvedic medical system [100]. In addition, T. purpurea has been used in the Unani medical system for the treatment of skin and other disorders associated with morbid blood, and also used as an important ingredient in blood purifier formulations [101]. In the course of our search for anti-allergic natural products from traditional herbal medicines [102, 103], T. purpurea was investigated based on bioassay-guided fractionation and isolation, which resulted in the isolation of an active principle. The structure of this compound was elucidated by spectroscopic analysis and chemical synthesis to be 4-methoxybenzofuran-5-carboxamide (99) (Fig. 22) [104]. An isomer of 99, 6-methoxybenzofuran-5-carboxamide, together with their demethyl derivatives, as well as derivatives whose carboxamide replaced with carboxylic acid, were also synthesized, and their activity on phorbol 12-myristate 13-acetate (PMA)induced H1R gene expression in HeLa cells was evaluated. Compound 99 suppressed H1R mRNA up-regulation in HeLa cells with an $\mathrm{IC}_{50}$ value of $75.3 \mu \mathrm{M}$, while its isomer, 6-methoxybenzofuran-5-carboxamide, suppressed H1R gene expression with an $\mathrm{IC}_{50}$ value of $49.1 \mu \mathrm{M}$. Among the evaluated derivatives, only 6-methoxybenzofuran-5-carboxylic acid showed similar level of activity $\left(\mathrm{IC}_{50} 84.6 \mu \mathrm{M}\right)$. Mechanism study of this compound revealed that $\mathbf{9 9}$ ameliorated allergic symptoms and suppressed the elevation of H1R and helper T cell type 2 (Th2) cytokine mRNAs in TDI-sensitized rats. Further study suggested that the mechanism of $\mathbf{9 9}$ for H1R gene suppression underlies the inhibition of PKC 8

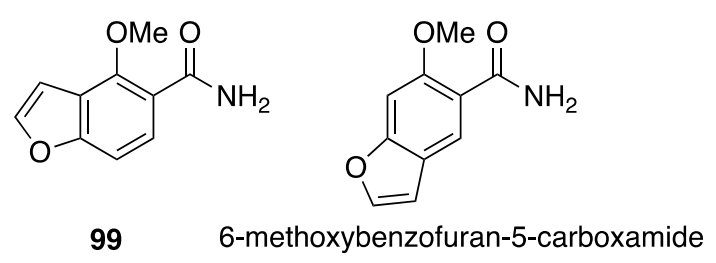

Fig. 22 The structures of benzofuran derivative (99) isolated from Tephrosia purpurea and its isomer as anti-allergic agents activation. In addition, it was shown that 99 alleviates nasal symptoms in TDI-sensitized rats through the inhibition of H1R and Th2 cytokine gene expression [105].

Myrtus communis, an evergreen sclerophyll shrub or small tree belonging to the Myrtaceae family, is widely distributed from the northwestern to the eastern Mediterranean, including bordering countries and western Asia [106]. This plant has been used as a spice, as well as for medicinal and food preparation purpose in various parts of the world since ancient Greece period, and is one of the important drugs being used in Unani and Ayurveda systems [107, 108]. Chemical constituents of the leaves of M. communis were investigated to give seven new phloroglucinol derivatives, including myrtucommunins A-D (100-103) and 6-methylisomyrtucommulone B (104) and 4-methylmyrtucommulone B (105) (Fig. 23), together with six known compounds including isomyrtucommulone B and myrtucommulone B. Myrtucommunins A-D (100-103) were assigned as conjugates of polymethylated acylphloroglucinol and flavonol L-rhamnoside, while 6-methylisomyrtucommulone B (104) and 4-methylmyrtucommulone B (105) were assigned as 6/6/6 tricyclic acylphloroglucinol derivatives with a racemic nature [109]. Racemic isomyrtucommulone B exhibited significant antimicrobial activities against Staphylococcus aureus including methicillin-resistant strains and Bacillus subtilis. Comparable antimicrobial activities were also found in the enantiomers (+)-isomyrtucommulone B and (-)-isomyrtucommulone B obtained by the chiral separation,<smiles></smiles><smiles>[R]c1c(O)c(C(=O)C(C)C)c(O)c2c1OC1=C(C(=O)C(C)(C)C(=O)C1(C)C)C2C(C)C</smiles>

$\mathrm{R}$

$104 \mathrm{Me}$

isomyrtucommulone $\mathrm{B} \quad \mathrm{H}$<smiles>[R]c1c(O)c(C(=O)C(C)C)c2c(c1O)C(C(C)C)C1=C(O2)C(C)(C)C(=O)C(C)(C)C1=O</smiles>

$R$

$105 \mathrm{Me}$ myrtucommulone $\mathrm{B} \quad \mathrm{H}$

Fig. 23 The structures of myrtucommunins A-D (100-103), phloroglucinol dimers (104 and 105), and isomyrtucommulone B, and myrtucommulone B isolated from Myrtus communis 
suggesting that the stereochemistry is not essential for its antimicrobial activity.

Butea monosperma (Lam.) Taub. (Fabaceae), commonly known as 'Flame of forest' or 'Palash', is a small to mediumsized deciduous tree widely distributed in tropical southern Asia up to an altitude of $4000 \mathrm{ft}$. Its roots have been used for elephantiasis and several eyesight defects, while the bark decoction has been used for the treatment of goiter, ulcer, dysentery, liver disorder and tumors [110]. In contrast, its flowers have been used as an emmenagogue, diuretic, depurative, and tonic, as well as for the treatment of leprosy, gout and skin diseases, spermatorrhea, and leucorrhoea [111]. The flowers of this plant are also used commercially as a natural dyeing due to their bright orange-red color. Several biological activities for the flowers of B. monosperma have been reported including antidiabetic, anticonvulsive, antiesterogenic, antioxidative, hepatoprotective, chemopreventive and anti-inflammatory activities, and some of which validated the traditional use of this plants [112]. However, their active components have not been clarified. We examined the flowers of Butea monosperma, resulting in the isolation of a new aurone glucoside and three new biflavonoids and some known flavonoids including butein, sulfurein, and monospermoside, coreopsin. The new aurone glucoside was characterized to be sulfuretin 3-O- $\beta$-glucopyranoside, while new biflavonoids were assigned as butin 3,3"-dimer (106), an auronoflavanone type biflavonoid (107) and a chalconoflavanone type biflavonoid (108), respectively. Compound 107 was the only auronoflavanone type biflavonoid linked between C-3 and C-6', while $\mathbf{1 0 8}$ was the first chalconoflavanone type biflavonoid linked between $\mathrm{C}-3$ and C-8"', and between C-2' and C-7"'" (Fig. 24) [113]. In an influenza A neuraminidase inhibitory assay, butein displayed relatively potent inhibitory activity with an $\mathrm{IC}_{50}$ value of $5.4 \mu \mathrm{g} / \mathrm{mL}$. Sulfuretin 3-O- $\beta$-glucopyranoside, monospermoside, and coreopsin showed moderate influenza A neuraminidase inhibitory activity with $\mathrm{IC}_{50}$ values ranging from 28.5 to $34.9 \mu \mathrm{g} / \mathrm{mL}$. By contrast, compound $\mathbf{1 0 8}$ showed potent activity in a DPPH free-radical scavenging assay with an $\mathrm{IC}_{50}$ value of $1.7 \mu \mathrm{g} / \mathrm{mL}$.

An Ayurvedic medicinal plant, Moringa oleifera Lam. (Moringaceae), is widely distributed in tropical areas [114]. The roots of M. oleifera is listed in the Indian Materia Medica as useful for the treatment of a number of ailments, including asthma, gout, lumbago, rheumatism, enlarged spleen or liver, internal deep-seated inflammations and calculi $[115,116]$. In contrast, the leaves, fruit, flowers and immature pods of this plant are used as a nutritive vegetable in India, Bangladesh, Pakistan, the Philippines, Hawaii and many parts of Africa [117-119]. Phytochemical study of the leaves of $M$. oleifera, resulted in the isolation of two new caffeoyl quinic acid glucosides (109 and 110), together with three known caffeoyl quinic acids, 3-O-, 4-O-, and 5 - $O$-caffeoyl quinic acids, as well as five known flavonoid glucosides including quercetin 3-O- $\beta$-D-(6"- $O$-malonyl)glucoside. The structures of new caffeoyl quinic acid glucosides were elucidated by spectroscopic analysis and chemi-

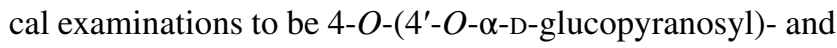
4-O-(3'-O- $\alpha$-D-glucopyranosyl)-caffeoyl quinic acids (109 and 110, respectively) (Fig. 25) [120]. Glucosides of secondary metabolites found in plants normally have a $\beta$-configuration, since a glucosyl moiety is usually provided from UDP-glucose by SN2 nucleophilic displacement reaction, yielding a $\beta$-glucoside. In contrast, the $\alpha$-glucosyl moiety is provided by ADP-glucose by SNi-like glucosyl transfer, and $\alpha$-glucosides of secondary metabolites isolated from plants are few [121-124]. From this viewpoint, 109 and $\mathbf{1 1 0}$ are biogenetically interesting secondary metabolites with an $\alpha$-linked glucopyranosyl residue. In an influenza A neuraminidase inhibitory assay, 3-O-caffeoyl- and 5-O-caffeoyl quinic acids displayed moderate inhibitory activity with $\mathrm{IC}_{50}$ values of 30.0 and $27.8 \mu \mathrm{g} / \mathrm{mL}$, respectively, while 4-O-caffeoyl quinic acid was less potent $\left(\mathrm{IC}_{50}\right.$ $67.0 \mu \mathrm{g} / \mathrm{mL})$. Quercetin 3-O- $\beta$-D-(6"-O-malonyl)-glucoside also showed moderate influenza A neuraminidase inhibitory activity, with an $\mathrm{IC}_{50}$ value of $25.3 \mu \mathrm{g} / \mathrm{mL}$.

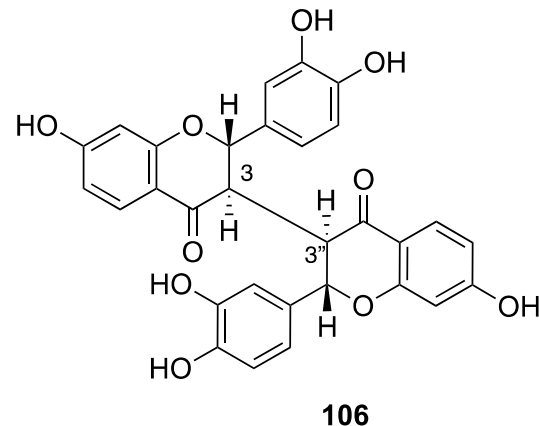

106

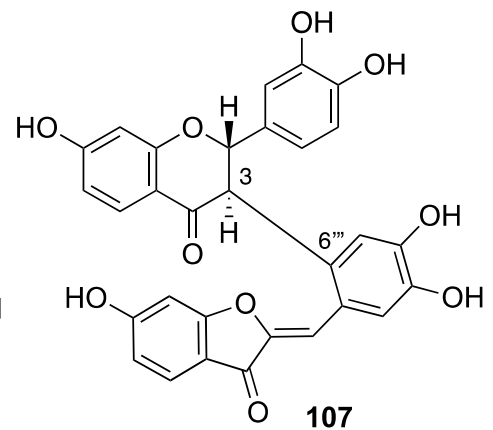

107

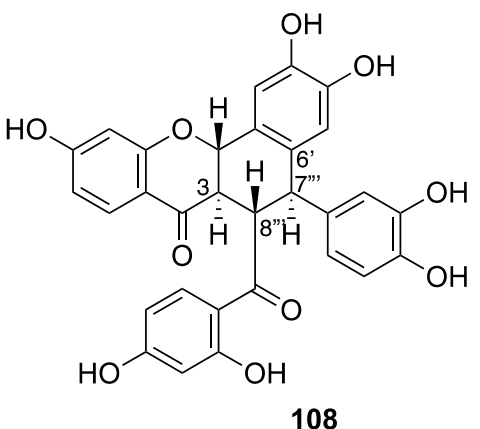

108

Fig. 24 The structures of new biflavonoids (106-108) from isolated Butea monosperma 


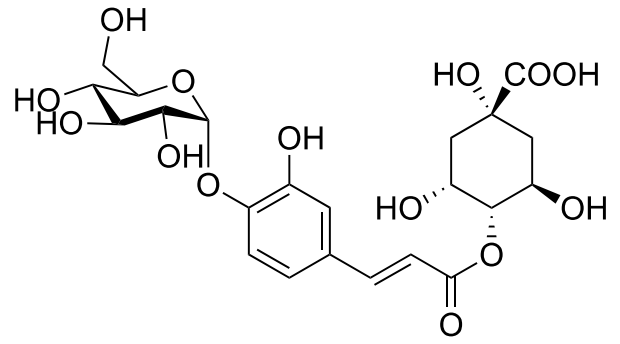

109<smiles>O=C(/C=C/c1ccc(O)c(OC2OC(O)C3OC(O)C(O3)C2O)c1)O[C@@H]1[C@@H](O)C[C@](O)(C(=O)O)C[C@H]1O</smiles>

110

Fig. 25 The structures of $\alpha$-D-glucopyranosyl caffeoyl quinic acids (109 and 110) isolated from Moringa oleifera

\section{Conclusion}

This review summarized phytochemical studies on traditional herbal medicines used in China, Mongolia, Uzbekistan, and Bangladesh, which were performed based on the ethnopharmacological information obtained by field studies or those exchanges collaborated with researchers of the respective regions. From traditional herbal medicines used in the regions above, together with a traditional herbal medicine related to one of those used in Hokkaido, diverse classes of new molecules were isolated, and their structures were elucidated on the basis of NMR, MS, and ECD analyses including a TDDFT ECD calculation method as well as chemical conversions. Our phytochemical studies on traditional herbal medicines uncovered structurally and biogenetically unique molecules.

In the studies on Chinese traditional herbal medicines especially used in Yunnan Province, and Guangxi Zhuang Autonomous Region, phytochemical studies of eight traditional herbal medicines, as well as one unexplored plant and one related herbal medicine used in Hokkaido, yielded several structurally unique molecules. Rigenolide A (1) isolated from Gentiana rigescens was a unique secoiridoid glucoside formed by intramolecular [2+2] cycloaddition, while rigenolides B (7) and C (8) were diastereomeric conjugates of a secoiridoid glucoside and a norsecoiridoid. Spicachlorantins C-F (11-14) isolated from Chloranthus spicatus were the first lindenane sesquiterpene dimers with a hydroperoxy group at $\mathrm{C}-4$, being considered to be biogenetic precursors for the corresponding hydroxy derivatives of dimeric lindenane sesquiterpenes. From the same genus plant, $C$. japonicus, which has been used by an ethnic minority group living in Hokkaido, hitorins A (16) and B (17), novel $\mathrm{C}_{25}$ terpenoids with a 6/5/5/5/5/3 hexacyclic skeleton, being considered to be biogenetically derived from eudesmane sesquiterpene and thujane monoterpene, were isolated.

The information of medicinal uses for Linaria buriatica and Lophanthus chinensis were obtained in the ethnopharmacological survey of Mongolian traditional herbal medicines, and they were found to be phytochemically unexplored plants. Linaburiosides A-D (47-50), iridoid glucosides possessing an iridoid derived acyl moiety, isolated from Linaria buriatica, whose iridoid derived acyl moiety were only found in Linaria plants. Algiolide A (57), isolated from a traditional herbal medicine, Gentiana algida, used in Mongolia, has a novel skeleton consisting of fused $\alpha, \beta$-unsaturated $\delta$-lactone and cyclopentene rings, being considered to be derived from gentiopicroside commonly exists in the Gentianaceous plants.

From Perovskia scrophulariifolia, an herbal medicine traditionally used in Uzbekistan, perovsfolins A (71) and $\mathrm{B}$ (72), possessing a $\mathrm{C}_{28}$ terpenoid moiety with unprecedented 6/8/6/6/6 pentacyclic carbon skeleton, were isolated, which were presumed to be produced by condensation of a 20-norabietane diterpene and methyl rosmarinate. Paeobrin (87) isolated from Paeonia hybrida possessed a new carbon framework, appeared to be derived from paeoniflorin as for lactiflorin and they were biogenetically related to each other, while paeonihybridin (86) had a hybrid structure consisted of paeoniflorin and paeonovicinoside. The first naturally occurring polyacetylen glucoside possessing an $\alpha$-pyrone moiety (81) was isolated from Mediasia macrophylla.

In contrast, in an evaluation of biological activities for the isolated compounds, a variety of activities including neuroinflammatory activity, antiproliferative activities against human tumor cell lines as well as reversing activity MDR of tumor cells, antimicrobial activities against various bacteria and fungus, antiviral activities against influenza $\mathrm{A}$ virus, or influenza A neuraminidase inhibitory activity, and anti-allergic activity through suppression of H1R mRNA up-regulation useful for therapeutic agents, as well as proproliferative activity on human follicle dermal papilla cells beneficial for hair care were also demonstrated.

Ethnopharmacological surveys have provided useful information for performing phytochemical study to find a variety of new molecules with unique structures and various biological activities. Our study results suggested that there are still many traditional herbal medicines should be explored as resources of new molecules as seeds of therapeutic agents. 
Acknowledgements We are grateful to Profs. H.-D. Sun and S.-L. Li, Kunming Institute of Botany, Chinese Academy of Sciences, Prof. D.-P. Li, Guangxi Key Laboratory of Functional, Phytochemicals Research and Utilization, Guangxi Institute of Botany, Guangxi Zhuang Autonomous Region and Chinese Academy of Sciences and Profs. D. Damdinjav and E. Dorjval, School of Pharmaceutical Biomedical Sciences, Mongolian National University of Medical Sciences, as well as all the other collaborators for their cooperation of ethnopharmacological survey in Yunnan, Guangxi, and Mongolia, respectively. We thank to Dr. Nilufar Z. Mamadalieva, Institute of the Chemistry of Plant Substances, Academy Sciences of the Republic of Uzbekistan, Dr. Olimjon K. Kodzhimatov, Institute of Botany and Botanical Garden, Uzbekistan Academy of Sciences, and Dr. F. A. Ahmed, Department of Botany, Faculty of Biological Sciences, Jahangirnagar University, Bangladesh for sharing ethnopharmacological information of traditional herbal medicines.

We also thank to Prof. Y. Takaishi and Dr. H. Shibata, Graduate School of Pharmaceutical Sciences, Tokushima University, Prof. K. Murakami, Faculty of Pharmaceutical Sciences, Sojo University, and Prof. K. Kawazoe, School of Pharmacy, Showa University for their help of ethnopharmacological survey and phytochemical studies.

Funding These works were partly supported by JSPS KAKENHI Grant numbers 15406032, 18406028, 22406024, and 26305003.

Open Access This article is licensed under a Creative Commons Attribution 4.0 International License, which permits use, sharing, adaptation, distribution and reproduction in any medium or format, as long as you give appropriate credit to the original author(s) and the source, provide a link to the Creative Commons licence, and indicate if changes were made. The images or other third party material in this article are included in the article's Creative Commons licence, unless indicated otherwise in a credit line to the material. If material is not included in the article's Creative Commons licence and your intended use is not permitted by statutory regulation or exceeds the permitted use, you will need to obtain permission directly from the copyright holder. To view a copy of this licence, visit http://creativecommons.org/licenses/by/4.0/.

\section{References}

1. Popovićn Z, Matić R, Bojović S, Stefanović M, Vidaković V (2016) Ethnobotany and herbal medicine in modern complementary and alternative medicine: an overview of publications in the field of I\&C medicine 2001-2013. J Ethnopharmacol 181:182-192

2. Gurib-Fakim A (2006) Medicinal plants: traditions of yesterday and drugs of tomorrow. Mol Aspects Med 27:1-93

3. Yang Y, Tian K, Hao J, Pei SJ, Yang YX (2004) Biodiversity and biodiversity conservation in Yunnan, China. Biodivers Conserv 13:813-826

4. Hou MF, López-Puol J, Qin HN, Wang LS, Yan L (2010) Distribution pattern and conservation priorities for vascular plants in Southern China: Guangxi Province as a case study. Bot Stud 51:377-386

5. Jiang RW, Wong KL, Chan YM, Xu HX, But PPH, Shaw PC (2005) Isolation of secoiridoid glycosides and comparative study on radix gentianae and related adulterants by HPLC analysis. Phytochemistry 66:2674-2680

6. Xu M, Wang D, Zhang YJ, Yang CR (2007) Dammarane triterpenoids from the roots of Gentiana rigescens. J Nat Prod $70: 880-883$
7. Suyama Y, Kurimoto S, Kawazoe K, Murakami K, Sun HD, Li SL, Takaishi Y, Kashiwada Y (2013) Rigenolide A, a new secoiridoid glucoside with a cyclobutane skeleton, and three new acylated secoiridoid glucosides from Gentiana rigescens Franch. Fitoterapia 91:166-172

8. Suyama Y, Tanaka N, Kawazoe K, Murakami K, Li SL, Sun HD, Kashiwada Y (2018) Rigenolides D-H, norsecoiridoid and secoiridoids from Gentiana rigescens Franch. J Nat Med 72:576-581

9. Suyama Y, Tanaka N, Kawazoe K, Murakami K, Li SL, Sun HD, Kashiwada Y (2017) Rigenolides B and C, conjugates of norsecoiridoid and secoiridoid glucosides from Gentiana rigescens Franch. Tetrahedron Lett 58:1459-1461

10. Wang AR, Song HC, An HM, Huang Q, Luo X, Dong JY (2015) Secondary metabolites of plants from the genus Chloranthus: chemistry and biological activities. Chem Biodivers 12:451-473

11. Kim SY, Kashiwada Y, Kawazoe K, Murakami K, Sun HD, Li SL, Takaishi Y (2009) Spicachlorantins A and B, new dimeric sesquiterpenes from the roots of Chloranthus spicatus. Phytochemistry Lett 2:110-113

12. Kawabata J, Mizutani J (1992) Dimeric sesquiterpenoid esters from Chloranthus serratus. Phytochemistry 31:1293-1296

13. Kawabata J, Fukushi E, Mizutani J (1995) Sesquiterpene dimers from Chloranthus japonicus. Phytochemistry 39:121-125

14. Xu YJ (2013) Phytochemical and biological studies of Chloranthus medicinal plants. Chem Biodivers 10:1754-1773

15. Yang XZ, Wang C, Yang J, Wan DR, Lin QX, Yang GZ, Mei ZN, Feng YJ (2014) Antimicrobial sesquiterpenes from the Chinese medicinal plant, Chloranthus angustifolius. Tetrahedron Lett 55:5632-5634

16. Wang LJ, Xiong J, Liu ST, Liu XH, Hu JF (2014) Sesquiterpenoids from Chloranthus henryi and their anti-neuroinflammatory activities. Chem Biodivers 11:919-928

17. Kim SY, Nagashima H, Tanaka N, Kashiwada Y, Kobayashi J, Kojoma M (2016) Hitorins A and B, hexacyclic $\mathrm{C}_{25}$ terpenoids from Chloranthus japonicus. Org Lett 18:5420-5423

18. Li XH, Zhai TR, He P, Wei Z, Wang Z (2019) Biomimetic synthesis of hitorins $\mathrm{A}$ and $\mathrm{B}$ via an intermolecular alkoxy radicalolefin coupling cascade. ChemRxiv. https://doi.org/10.26434/ chemrxiv.9882980.v1

19. Fan JT, Kuang B, Zeng GZ, Zhao SM, Ji CJ, Zhang YM, Tan NH (2011) Biologically active arborinane-type triterpenoids and anthraquinones from Rubia yunnanensis. J Nat Prod 74:2069-2080

20. Suyama Y, Tanaka N, Tanano Y, Yagi H, Kawazoe K, Murakami K, Li SL, Sun HD, Kashiwada Y (2017) Stereochemical assignments of rubiaquinones A-C, naphthoquinone derivatives from Rubia yunnanensis. Tetrahedron Lett 58:4568-4571

21. Shang X, He X, He X, Li M, Zhang R, Fan P, Zhang Q, Jia $\mathrm{Z}$ (2010) The genus Scutellaria an ethnopharmacological and phytochemical review. J Ethnopharmacol 128:279-313

22. Ministry of Health (2016) Labour and Welfare of Japan. The Japanese Pharmacopoeia, 17th edn. Tokyo

23. Pharmacopoeia Commission Ministry of Public Health (2015) Pharmacopoeia of the People's Republic in China. Part 1. Beijing

24. Awad R, Arnason JT, Trudeau V, Bergeron C, Budzinski JW, Foster BC (2003) Phytochemical and biological analysis of Skullcap (Scutellaria lateriflora L.): a medicinal plant with anxiolytic properties. Phytomedicine 10:640-649

25. Wang TS, Wang SQ, Xiao DL (2012) A review of phytochemistry and antitumor activity of a valuable medicinal species: Scutellaria barbata. J Med Plants Res 6:4259-4275

26. Kurimoto S, Pu JX, Sun HD, Takaishi Y, Kashiwada Y (2015) Coleifolides A and B, two new sesterterpenoids from the aerial parts of Scutellaria cleifolia Levl. Chem Biodivers 12:1200-1207 
27. Piao SJ, Zhang HJ, Lu HY, Yang F, Jiao WH, Yi YH, Chen WS, Lin HW (2011) Hippolides A-H, acyclic manoalide derivatives from the marine sponge Hippospongia lachne. J Nat Prod 74:1248-1254

28. Kurimoto S, Pu JX, Sun HD, Takaishi Y, Kashiwada Y (2015) Acylated neo-clerodanes and 19-nor-neo-clerodanes from the aerial parts of Scutellaria coleifolia (Lamiaceae). Phytochemistry 116:298-304

29. Kurimoto S, Pu JX, Sun HD, Takaishi Y, Kashiwada Y (2016) Acylated neo-clerodane type diterpenoids from the aerial parts of Scutellaria coleifolia Levl. (Lamiaceae). J Nat Med 70:241-252

30. Hong L, Guo Z, Huang K, Wei SJ, Liu B, Meng SW (2015) Ethnobotanical study on medicinal plants used by Maonan people in China. J Ethnobiol Ethnomed 11:32

31. Qi SH, Wu DG, Chen L, Ma YB, Luo XD (2003) Insect antifeedants from Munronia henryi: structure of munroniamide. J Agric Food Chem 51:6949-6952

32. Yang XR, Tanaka N, Tsuji D, Lu FL, Yan XJ, Itoh K, Li DP, Kashiwada Y (2019) Limonoids from the aerial parts of Munronia pinnata. Tetrahedron 75:13079

33. Li Y, Zhang DM, Li JB, Yu SS, Li Y, Luo YM (2006) Hepatoprotective sesquiterpene glycosides from Sarcandra glabra. J Nat Prod 69:616-620

34. Yang XR, Tanaka N, Tsuji D, Lu FL, Yan XJ, Itoh K, Li DP, Kashiwada $Y$ (2020) Sarcaglabrin A, a conjugate of $C_{15}$ and $C_{10}$ terpenes from the aerial parts of Sarcandra glabra. Tetrahedron Lett 61:151916

35. Ye Q, Qiu Y, Quo Y, Chen J, Yang S, Zhao M, Fu C (2006) Species-specific SCAR markers for authentication of Sinocalycanthus chinensis. J Zhejiang Univ Sci B 7:868-872

36. Li J, Jin Z (2006) High genetic differentiation revealed by RAPD analysis of narrowly endemic Sinocalycanthus chinensis Cheng et S.Y. Chang, an endangered species of China. Biochem Syst Ecol 34:725-735

37. Dictionary of Traditional Chinese Medicine (1977) Jiangsu New Medical College (Ed.) Shanghai Science and Technology Press, Shanghai, p 1829

38. Kashiwada Y, Nishimura K, Kurimoto S, Takaishi Y (2011) New 29-nor-cycloartanes with a 3,4-seco- and a novel 2,3-secostructure from the leaves of Sinocalycanthus chinensis. Bioorg Med Chem 19:2790-2796

39. Lee D, Cuendet M, Axelrod F, Chavez PI, Fong HHS, Pezzutoa JM, Kinghorn AD (2001) Novel 29-nor-3,4-seco-cycloartane triterpene methyl esters from the aerial parts of Antirhea acutata. Tetrahedron 57:7107-7112

40. Lee D, Park EJ, Cuendet M, Axelrod F, Chavez PI, Fong HHS, Pezzutoa JM, Kinghorn AD (2001) Cyclooxygenase-inhibitory and antioxidant constituents of the aerial parts of Antirhea acutat. Bioorg Med Chem Lett 11:1565-1568

41. Dictionary of Traditional Chinese Medicine (1977) Jiangsu New Medical College (Ed.) Shanghai Science and Technology Press, Shanghai, pp 1403-1405

42. Kurokawa M, Yamamura J, Li Z, Sato H, Hitomi N, Tatsumi Y, Shiraki K (1998) Antipyretic activity of Gingyo-san, a traditional medicine, in influenza virus-infected mice. Chem Pharm Bull 46:1444-1447

43. Shibata H, Higuti T, Kirimoto T (2010) Antiviral agent. Jpn Kokai Tokkyo Koho, JP-2010-83758A

44. Kashiwada Y, Omichi Y, Kurimoto S, Shibata H, Miyake Y, Kirimoto T, Takaishi Y (2013) Conjugates of a secoiridoid glucoside with a phenolic glucoside from the flower buds of Lonicera japonica Thunb. Phytochemistry 96:423-429

45. Wu YB, Ni ZY, Shi QW, Dong M, Kiyota H, Gu YC, Cong B (2012) Constituents from Salvia species and their biological activities. Chem Rev 112:5976-6026
46. Hirata A, Kim SY, Kobayakawa N, Tanaka N, Kashiwada Y (2015) Miltiorins A-D, diterpenes from Radix Salviae miltiorrhizae. Fitoterapia 102:49-55

47. Gonchig E, Erdenebat S, Togtoo O, Bataa S, Gendaram O, Kim YS, Ryu SY (2008) Antimicrobial activity of Mongolian medicinal plants. Nat Prod Sci 14:32-36

48. Pitschmann A, Purevsuren S, Obmann A, Natsagdorj D, Gunbilig D, Narantuya S, Kletter Ch, Glasl S (2013) Traditional Mongolian medicine: history and status quo. Phytochem Rev 12:943-959

49. Batugal PA, Jayashree K, Lee SY, Jeffrey TO (eds) (2004) Medicinal plants research in Asia, volume 1: the framework and project work plans. International Plant Genetic Resources Institute-Regional Office for Asia, the Pacific and Oceania (IPGRI-APO), Serdang, Selangor DE, Malaysia, pp 127-139

50. Handjieva NV, Ilieva EI, Spassov SL, Popov SS, Duddeck H (1993) Iridoid glycosides from Linaria species. Tetrahedron 49:9261-9266

51. Deyuan H, Hanbi Y, Cunli J, Holmgren NH (1998). In: Wu ZY, Peter HR (eds) Flora of China. Science Press, Missouri Botanical Garden, Beijing, St. Louis, pp 49-52

52. Niwa K, Yia R, Tanaka N, Kitaguchi S, Tsuji D, Kim SY, Tsogtbaatar A, Bunddulam P, Kawazoe K, Kojoma M, Damdinjav D, Itoh K, Kashiwada Y (2020) Linaburiosides A-D, acylated iridoid glucosides from Linaria buriatica. Phytochemistry $171: 112247$

53. Otsuka H (1994) Iridolinarins A, B, and C: iridoid esters of an iridoid glucoside from Linaria japonica. J Nat Prod 57:357-362

54. Dirmenci T, Yildiz B, Hedge IC, Firat M (2010) Lophanthus (Lamiaceae) in Turkey: a new generic record and a new species. Turk J Bot 34:123-129

55. Celep F, Dirmenci T (2017) Systematic and biogeographic overview of Lamiaceae in Turkey. Nat Volatiles Essent Oils 4:14-27

56. Tanaka N, Yamada K, Shimomoto Y, Tsuji D, Itoh K, Kawazoe K, Damdinjav D, Dorjval E, Kashiwada Y (2020) Lophachinins A-E, abietane diterpenes from a Mongolian traditional herbal medicine Lophanthus chinensis. Fitoterapia 146:104702

57. Medicinal Plants in Mongolia (2013) World Health Organization Regional Office for the Western Pacific, Manila, pp 64-66

58. Tanaka N, Takekata M, Kurimoto S, Kawazoe K, Murakami K, Damdinjav D, Dorival E, Kashiwada Y (2015) Algiolide A, secoiridoid glucoside from Mongolian medicinal plant Gentiana algida. Tetrahedron Lett 56:817-819

59. Struwe L (2014) Classification and evolution of the family Gentianaceae. In: Rybczyński JJ, Davey MR, Mikula A (eds) The Gentianaceae. Characterization and ecology, vol 1. Springer, Berlin, pp 13-35

60. Li MH, Zhou LS, Fang HY, Song XL, Zhang N (2010) Quantification of xanthones in a Mongolian health tea using high-performance liquid chromatography. J Med Plants Res 4:1704-1707

61. Lu S, Tanaka N, Kawazoe K, Murakami K, Damdinjav D, Dorjbal E, Kashiwada Y (2016) Tetrahydroxanthones from Mongolian medicinal plant Gentianella amarella ssp. acuta. J Nat Med 70:780-788

62. Yang SC, Ruan JY, Liu YX, Ding ZJ, Ni YJ, Wang T, Zhang Y (2018) Bioactive xanthones from whole plants of Gentianella acuta. Chin Herb Med 10:99-102

63. Kirk PM, Cannon PF, Minter DW, Stalpers JA (2008) Dictionary of the fungi, 10th edn. CABI, Wallingford

64. Sagayama K, Tanaka N, Fukumoto T, Kashiwada Y (2019) Lanostane-type triterpenes from the sclerotium of Inonotus obliquus (Chaga mushrooms) as proproliferative agents of human follicle dermal papilla cells. J Nat Med 73:597-601 
65. Azzouni F, Godoy A, Li Y, Mohler J (2012) The 5 alpha-reductase isozyme family: a review of basic biology and their role in human diseases. Adv Urol 2012:530121

66. Mamadalieva NZ, Akramov DK, Ovidi E, Tiezzi A, Nahar L, Azimova SS, Sarker SD (2017) Aromatic medicinal plants of the Lamiaceae family from Uzbekistan: ethnopharmacology, essential oils composition, and biological activities. Medicines 4:8

67. Khojimatov OK, Khamraeva DT, Khujanov AN, Bussmann RW (2020) An overview of ethnomedicinal plants of Uzbekistan. Ethnobot Res Appl 20:08

68. Egamberdieva D, Mamedov N, Ovidi E, Tiezzi A, Craker L (2016) Phytochemical and pharmacological properties of medicinal plants from Uzbekistan: a review. J Med Active Plants 5:59-75

69. Pourhosseini SH, Hadian J, Sonboli A, Nejad Ebrahimi S, Mirjalili MH (2018) Genetic and chemical diversity in Perovskia abrotanoides KAR. (Lamiaceae) populations based on ISSRs markers and essential oils profile. Chem Biodivers 15:e1700508

70. Tanaka N, Niwa K, Kajihara S, Tsuji D, Itoh K, Mamadalieva NZ, Kashiwada Y (2020) $\mathrm{C}_{28}$ terpenoids from Lamiaceous plant Perovskia scrophulariifolia: their structures and antineuroinflammatory activity. Org Lett 22:7667-7670

71. Tanaka N, Takahashi S, Kajihara S, Tsuji D, Itoh K, Mamadalieva NZ, Kashiwada Y (2021) Diterpenes from an Uzbek medicinal plant Perovskia scrophulariifolia: their structures and anti-neuroinflammatory activity. Fitoterapia 149:104826

72. Suzuki K, Okasaka M, Kashiwada Y, Takaishi Y, Honda G, Ito M, Takeda Y, Kodzhimatov OK, Ashurmetov O, Sekiya M, Ikeshiro Y (2007) Sesquiterpene lactones from the roots of Ferula varia and their cytotoxic activity. J Nat Prod 70:1915-1918

73. Kurimoto S, Suzuki K, Okasaka M, Kashiwada Y, Kodzhimatov OK, Takaishi Y (2012) Sesquiterpene lactone glycosides from the roots of Ferula varia. Chem Pharm Bull 60:913-919

74. Kurimoto S, Suzuki K, Okasaka M, Kashiwada Y, Kodzhimatov OK, Takaishi Y (2012) New sesquiterpene lactone glucosides from the roots of Ferula varia. Phytochemistry Lett 5:729-733

75. Chernenko TV, Glushenkova AI, Nigmatullaev AM (2002) Lipids from Mediasia macrophylla leaves. Chem Nat Comp 38:307-309

76. Kurimoto S, Okasaka M, Kashiwada Y, Kodzhimatov OK, Takaishi Y (2010) A C $_{14}$-polyacetylenic glucoside with an $\alpha$-pyrone moiety and four new $\mathrm{C}_{10}$-polyacetylenic glucosides from Mediasia macrophylla. Phytochemistry 71:688-692

77. Christensen LP, Brand K (2006) Bioactive polyacetylenes in food plants of the Apiaceae family: occurrence, bioactivity and analysis. J Pharm Biomed Anal 41:683-693

78. Minto RE, Blacklock BJ (2008) Biosynthesis and function of polyacetylenes and allied natural products. Prog Lipid Res 47:233-306

79. Jelodarian Z, Shokoohinia Y, Rashidi M, Ghiasvand N, Hosseinzadeh L, Iranshahi M (2017) New polyacetylenes from Echinophora cinerea (Boiss.) Hedge et Lamond. Nat Prod Res 31:2256-2263

80. Geng CA, Yang TH, Huang XY, Yang J, Ma YB, Li TZ, Zhang XM, Chen JJ (2018) Anti-hepatitis B virus effects of the traditional Chinese herb Artemisia capillaris and its active enynes. J Ethnopharmacol 224:283-289

81. Wu SH, Wu DG, Chen YW (2010) Chemical constituents and bioactivities of plants from the genus Paeonia. Chem Biodivers 7:90-104

82. Konovalov MN, Kuvaev VB, Trutneva ZA (1962) New data in the medical use of Paeonia anomala. Med Prom SSSR 5:57-59

83. Okasaka M, Kashiwada Y, Kodzhimatov OK, Ashurmetov O, Takaishi Y (2008) Monoterpene glycosides from Paeonia hybrida. Phytochemistry 69:1767-1772
84. Lang HY, Li SZ, Wang HB, Yu DQ, Liang XT (1990) The structure of lactiflorin, an artifact during isolation? Tetrahedron 46:3123-3128

85. Ha DT, Trung TN, Thuan ND, Yim NH, Min B, Bae KH (2010) Lipoxygenase inhibitory and antioxidant activities of isolated compounds from Moutan Cortex. Nat Prod Sci 16:68-74

86. Tavares WR, Seca AML (2018) The current status of the pharmaceutical potential of Juniperus L. metabolites. Medicines 5:81

87. Shalyt MS (1951) Wild-growing useful plants of Turkmen SSR, Moscow, p 222

88. Karriev MO (1967) Comparative characteristics of essential oils at Central Asian species of Juniperus. Acad Nauk Turkm SSR Ser Bio Nauk 1:40-43

89. Okasaka M, Takaishi Y, Kashiwada Y, Kodzhimatov OK, Ashurmetov O, Lin AJ, Consentino LM, Lee KH (2006) Terpenoids from Juniperus polycarpus var. seravschanica. Phytochemistry 67:2635-2640

90. Ishida S, Okasaka M, Ramos F, Kashiwada Y, Takaishi Y, Kodzhimatov OK, Ashurmetov O (2008) New alkaloid from the aerial parts of Codonopsis clematidea. J Nat Med 62:236-238

91. Shibano M, Tsukamoto D, Masuda A, Tanaka Y, Kusano G (2001) Two new pyrrolidine alkaloids, radicamines A and B, as inhibitors of $\alpha$-glucosidase from Lobelia chinensis Lour. Chem Pharm Bull 49:1362-1365

92. Tsou EL, Chen SY, Yang MH, Wang SC, Cheng TRR, Cheng WC (2008) Synthesis and biological evaluation of a 2-aryl polyhydroxylated pyrrolidine alkaloid-based library. Bioorg Med Chem 16:10198-10204

93. Sarwar AKMG (2015) Medicinal plant genetic resources of Bangladesh-genera represented by single species and their conservation needs. J Med Plants Stud 3:65-74

94. Kaisar MA, Rahman MS, Rahman MZ, Hasan CM, Rashid MA (2011) A review on phytochemicals from some medicinal plants of Bangladesh. J Pharm Nutr Sci 1:87-95

95. World Health Organization, Programme on Traditional Medicine. (2001) Legal status of traditional medicine and complementary/alternative medicine: a worldwide review. World Health Organization

96. Rahmatullah M, Ferdausi D, Mollik MAH, Azam MNK, TaufiqUr-Rahman M, Jahan R (2009) Ethnomedicinal survey of Bheramara area in Kushtia district, Bangladesh. Am-Eurasian J Sustain Agric 3:534-541

97. Buttertterworth JH, Morgan ED (1968) Isolation of a substance that suppresses feeding in locust. J Chem Soc Chem Commun 1968:23-24

98. Govindachari TR (1992) Chemical and biological investigations on Azadirachta indica (the neem tree). Curr Sci 63:117-122

99. Kurimoto S, Takaishi Y, Ahmed FA, Kashiwada Y (2014) Triterpenoids from the fruits of Azadirachta indica (Meliaceae). Fitoterapia 92:200-205

100. Dalwadi PP, Patel JL, Patani PV (2014) Tephrosia purpurea Linn (Sharpunkha, Wild Indigo): a review on phytochemistry and pharmacological studies. Indian J Pharm Biol Res 2:108-121

101. Ansari M, Jahan N (2019) Tephrosia purpurea (L.) Pers. (Sarphuka, Wild Indigo): an important drug of Unani system of medicine. Discov Phytomed 6:61-69

102. Mizuguchi H, Nariai Y, Kato S, Nakano T, Kanayama T, Kashiwada Y, Nemoto H, Kawazoe K, Takaishi Y, Kitamura Y, Takeda $\mathrm{N}$, Fukui H (2015) Maackiain is a novel antiallergic compound that suppresses transcriptional upregulation of the histamine H1receptorand interleukin-4 genes. Pharmcol Res Perspect 3:e00166

103. Fukui H, Mizuguchi H, Nemoto H, Kitamura Y, Kashiwada Y, Takeda $\mathrm{N}$ (2016) Histamine $\mathrm{H}_{1}$ receptor gene expression and drug action of antihistamines. Handb Exp Pharmacol 241:161-169 
104. Shill MK, Das AK, Itou T, Karmakar S, Mukherjee PK, Mizuguchi H, Kashiwada Y, Fukui H, Nemoto H (2015) The isolation and synthesis of a novel benzofuran compound from Tephrosia purpurea, and the synthesis of several related derivatives, which suppress histamine $\mathrm{H}_{1}$ receptor gene expression. Bioorg Med Chem 23:6869-6874

105. Shill MC, Mizuguchi H, Karmakar S, Kadota T, Mukherjee PK, Kitamura Y, Kashiwada Y, Nemoto H, Takeda N, Fukui H (2016) A novel benzofuran, 4-methoxybenzofuran-5-carboxamide, from Tephrosia purpurea suppressed histamine $\mathrm{H}_{1}$ receptor gene expression through a protein kinase $\mathrm{C} \delta$-dependent signaling pathway. Int Immunopharmacol 30:18-26

106. Aleksic V, Knezevic P (2014) Antimicrobial and antioxidative activity of extracts and essential oils of Myrtus communis L. Microbiol Res 169:240-254

107. Sumbul S, Ahmad MA, Asif M, Akhtar M (2011) Myrtus communis Linn.-a review. Indian J Nat Prod Resour 2:395-402

108. Arya V (2011) A review on anti-tubercular plants. Int $\mathbf{J}$ Pharmtech Res 3:872-880

109. Tanaka N, Jia Y, Niwa K, Imabayashi K, Tatano Y, Yagi H, Kashiwada Y (2018) Phloroglucinol derivatives and a chromone glucoside from the leaves of Myrtus communis. Tetrahedron 74:117-123

110. Sharma AK, Deshwal N (2011) An overview: on phytochemical and pharmacological studies of Butea monosperma. Int J Pharmtech Res 3:864-871

111. Burli DA, Khade AB (2007) A comprehensive review on Butea monosperma (Lam.) Kuntze. Phcog Rev 1:333-337

112. Sindhia VR, Bairwa R (2010) Plant review: Butea monosperma. Int J Pharm Clin Res 2:90-94

113. Ahmed FA, Kim SY, Kurimoto S, Sasaki H, Shibata H, Kashiwada Y, Takaishi Y (2011) Biflavonoids from flowers of Butea monosperma (LAM.) TAUB. Heterocycles 83:2079-2089
114. Sastri BN (1962) The wealth of India. Council of Scientific and Industrial Research, New Delhi

115. Basu BD, Kirtikar KR (1980) Indian medicinal plants, vol 1. International Book Distributors, Dehradun, pp 676-683

116. Vaidyaratnam PSV (1994) Indian medicinal plants: a compendium of 500 species, vol 4. Orient Longman, Madras, pp 59-64

117. Anwar F, Bhanger MI (2003) Analytical characterization of Moringa oleifera seed oil grown in temperate regions of Pakistan. J Agric Food Chem 51:6558-6563

118. Anwar F, Ashraf M, Bhanger MI (2005) Interprovenance variation in the composition of Moringa oleifera oilseeds from Pakistan. J Am Oil Chem Soc 82:45-51

119. Eilert U, Wolters B, Nahrstedt A (1981) Moringa oleifera and Moringa stenopetala. Planta Med 42:55-61

120. Kashiwada Y, Ahmed FA, Kurimoto S, Kim SY, Shibata H, Fujioka T, Takaishi Y (2012) New $\alpha$-glucosides of caffeoyl quinic acid from the leaves of Moringa oleifera Lam. J Nat Med $66: 217-221$

121. Ullah N, Ahmed S, Muhammad P, Ahmed Z, Nawaz HR, Malik A (1999) Coumarinolignoid glycoside from Daphne oleoides. Phytochemistry 51:103-105

122. Shi SY, Zhou Q, Peng H, Zhou CX, Hu MH, Tao QF, Hao XJ, Stöckigt J, Zhao Y (2007) Four new constituents from Taraxacum mongolicum. Chin Chem Lett 18:1367-1370

123. Cuong NX, Nhiem NX, Thao NP, Nama NH, Dat NT, Anh HLT, Huong LM, Kiem PV, Minh CV, Wonc JH, Chung WY, Kim YH (2010) Inhibitors of osteoclastogenesis from Lawsonia inermis leaves. Bioorg Med Chem Lett 20:4782-4784

124. She G, Guo Z, Lv H, She D (2009) New flavonoid glycosides from Elsholtzia rugulosa Hemsl. Molecules 14:4190-4196

Publisher's Note Springer Nature remains neutral with regard to jurisdictional claims in published maps and institutional affiliations.

\section{Authors and Affiliations}

\section{Naonobu Tanaka ${ }^{1}$ (D) $\cdot$ Yoshiki Kashiwada ${ }^{1}$ [D}

Yoshiki Kashiwada

kasiwada@tokushima-u.ac.jp
1 Graduate School of Pharmaceutical Sciences, Tokushima University, Tokushima 770-8505, Japan 